\title{
Review \\ GGCX-Associated Phenotypes: An Overview in Search of Genotype-Phenotype Correlations
}

\author{
Eva Y. G. De Vilder, Jens Debacker and Olivier M. Vanakker * \\ Center for Medical Genetics Ghent, Ghent University Hospital, Ghent 9000, Belgium; \\ eva.devilder@ugent.be (E.Y.G.D.V.); jensm.debacker@ugent.be (J.D.) \\ * Correspondence: olivier.vanakker@ugent.be; Tel.: +32-932-36-03 \\ Academic Editor: Nicholas Delihas \\ Received: 31 October 2016; Accepted: 13 January 2017; Published: 25 January 2017
}

\begin{abstract}
Gamma-carboxylation, performed by gamma-glutamyl carboxylase (GGCX), is an enzymatic process essential for activating vitamin K-dependent proteins (VKDP) with important functions in various biological processes. Mutations in the encoding GGCX gene are associated with multiple phenotypes, amongst which vitamin K-dependent coagulation factor deficiency (VKCFD1) is best known. Other patients have skin, eye, heart or bone manifestations. As genotype-phenotype correlations were never described, literature was systematically reviewed in search of patients with at least one GGCX mutation with a phenotypic description, resulting in a case series of 47 patients. Though this number was too low for statistically valid correlations-a frequent problem in orphan diseases-we demonstrate the crucial role of the horizontally transferred transmembrane domain in developing cardiac and bone manifestations. Moreover, natural history suggests ageing as the principal determinant to develop skin and eye symptoms. VKCFD1 symptoms seemed more severe in patients with both mutations in the same protein domain, though this could not be linked to a more perturbed coagulation factor function. Finally, distinct GGCX functional domains might be dedicated to carboxylation of very specific VKDP. In conclusion, this systematic review suggests that there indeed may be genotype-phenotype correlations for GGCX-related phenotypes, which can guide patient counseling and management.
\end{abstract}

Keywords: gamma-carboxylation; GGCX; cutis laxa; pseudoxanthoma elasticum; VKCFD1; elastic fibers

\section{Introduction}

The gamma-glutamyl carboxylase enzyme (GGCX) catalyzes the conversion of specific glutamate (Glu) residues to gamma-carboxyglutamate (Gla) residues, a process called gamma-carboxylation [1]. This posttranslational modification process uses vitamin $\mathrm{K}(\mathrm{VK})$ as an essential cofactor and is part of the so-called VK cycle (Figure 1) [2]. Gamma-carboxylation is essential in the activation and proper functioning of multiple VK-dependent proteins (VKDP), the most well-known of which are involved in blood clotting, including coagulation factors (FII, FVII, FIX and FX) and natural anti-clotting agents (protein C, protein S (ProS; OMIM*176880) and protein Z). Moreover, GGCX catalyzes gamma-carboxylation of other VKDP, involved in various biological processes such as inflammation (e.g., ProS, and gla-rich protein (GRP)), bone formation (osteocalcin (OC; OMIM*112260)), cell proliferation (growth arrest-specific 6 (Gas6; OMIM*600441)) and soft tissue mineralization (matrix gla protein (MGP; OMIM*154870)) [3,4]. Finally, several VKDP have a currently unknown function (proline-rich gla proteins (PRGP), and transmembrane gla proteins (TMG)) [1,2,5-7]. 


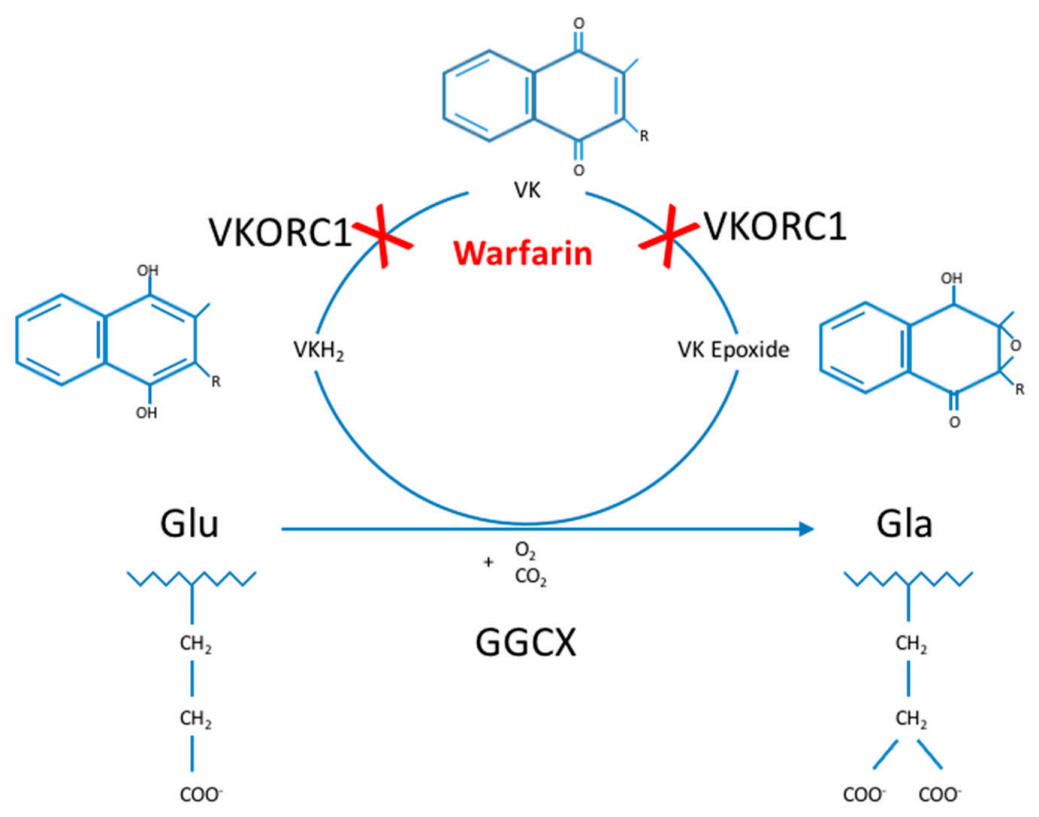

Figure 1. The Vitamin $\mathrm{K}$ cycle. Glu-residues are gamma-carboxylated by GGCX to Gla-residues, an enzymatic process using $\mathrm{VKH}_{2}, \mathrm{O}_{2}$ and $\mathrm{CO}_{2}$ as cofactors. During this process, $\mathrm{VKH}_{2}$ is oxidized to VK epoxide, which is then reduced to VK and in a second reduction step to $\mathrm{VKH}_{2}$ by VKORC1. Then, $\mathrm{VKH}_{2}$ can be reused, the reason for which this process is called the VK cycle. Gamma-carboxylation is only performed in VKDP and is essential for their activation and downstream functioning in multiple biological processes, such as blood clotting, bone formation, inflammation and cell proliferation. Warfarin inhibits the VK cycle by preventing VK reduction. C: carbon; GGCX: gamma-glutamyl carboxylase; Gla: gamma-carboxyglutamate; Glu: glutamate; H: hydrogen; O: oxygen; R: attached hydrogen or a hydrocarbon side chain of any length; VK: vitamin K (quinone); VKDP: VK-dependent proteins; $\mathrm{VKH}_{2}$ : vitamin $\mathrm{K}$ hydroquinone; VKORC1: vitamin $\mathrm{K}$ epoxide reductase complex, subunit 1.

The GGCX enzyme is encoded by the GGCX gene, located on the reverse strand of chromosome 2p11.2 (chromosomal position in assembly GRCh38.p7: 85,544,723-85,561,509). The gene is not considered to be polymorphic, as, according to the gnomAD database (combining data from the ExAc and 1000 genomes databases), of the 409 exonic variants (missense and loss-of-function) that have been identified in the GGCX gene, only two variants, i.e., rs699664 and rs6173310, have an allele frequency of $>0.0001$ (Table S1) [8].

GGCX has 10 transcripts, of which the longest is NM000821.6 (ENST00000233838.8; Uniprot P38435), comprising 15 exons and 7569 nucleotides. The protein encoded by this transcript is a $94 \mathrm{kDa}, 758$ amino acid (AA) transmembrane protein, expressed ubiquitously throughout the body and localized on the lipid membrane of the endoplasmic reticulum (ER). The N-terminal part of GGCX is localized in the cytoplasm, followed by 5 transmembrane domains (TMD), and the C-terminal portion is localized in the ER lumen (Figure 2). To date, the crystal structure of the GGCX enzyme is still incompletely resolved [9].

GGCX has multiple highly conserved domains (Figure 2), including the horizontally transferred transmembrane domain (HTTM-AA 56-315), spanning the first four TMDs, the function of which is currently unclear in humans [10]. Interestingly, in multiple species such as eukaryotes, bacteria and archae, the HTTM-domain seems to play an important role in VK-dependent carboxylation [11]. Within the TMD, the proline-residue at position 378 in TMD5 is proposed to play an important role in the correct orientation of GGCX; replacing that proline by a leucine leads to an important decrease in the formation of a disulfide bond in the protein, which is an important posttranslational modification step (see below) [12]. However, apart from the disulfide bond other factors must play a role in GGCX orientation, as even with a removal of the disulfide bond and a complete cleavage of GGCX 
between TMD4 and TMD5, the GGCX protein domains remain close together. Tie et al. suggested that an interaction between TMD2 and TMD5 could play an important role in this process [12]. Other important functional domains in the GGCX enzyme are the propeptide binding site (most recently proposed to be localized at AA 491-507), suggested as the primary location of interaction between GGCX and its substrates, and the glutamate binding site (AA 393-404), which interacts with the Glu-containing regions of VKDP, a necessary step for gamma-carboxylation. Interestingly, L394 and W399, which are localized in this predicted glutamate binding region, seem to play a role in polypeptide binding by GGCX, hereby stimulating the connection between the propeptide binding sites and the glutamate binding sites, thus facilitating gamma-carboxylation [9,13-15]. GGCX is further predicted to contain an RmlC (deoxythymidine-6-deoxy-D-xylo-4-hexulose 3,5 epimerase; EC5.1.3.13)-like jelly roll fold, comprising a double-stranded beta-helix jelly roll fold as is identified in RmlC, from AA 526 until 607 [11]. The function of this domain is however currently unclear.

Finally, GGCX also undergoes posttranslational modifications, such as glycosylation of 4 asparagine residues (AA 459, 550, 605 and 627) and the formation of a disulfide bond (between cysteine-residue 99 and 450), which stabilizes the protein leading to a more efficient enzymatic function [16-18]. GGCX further has 2 autocarboxylating Gla-domains, suggested to be localized at AA 625-647 and 729-758 in the C-terminal region of the enzyme in the ER lumen. Possibly, these Gla-domains have a yet undiscovered role in other processes than VKDP gamma-carboxylation [19].

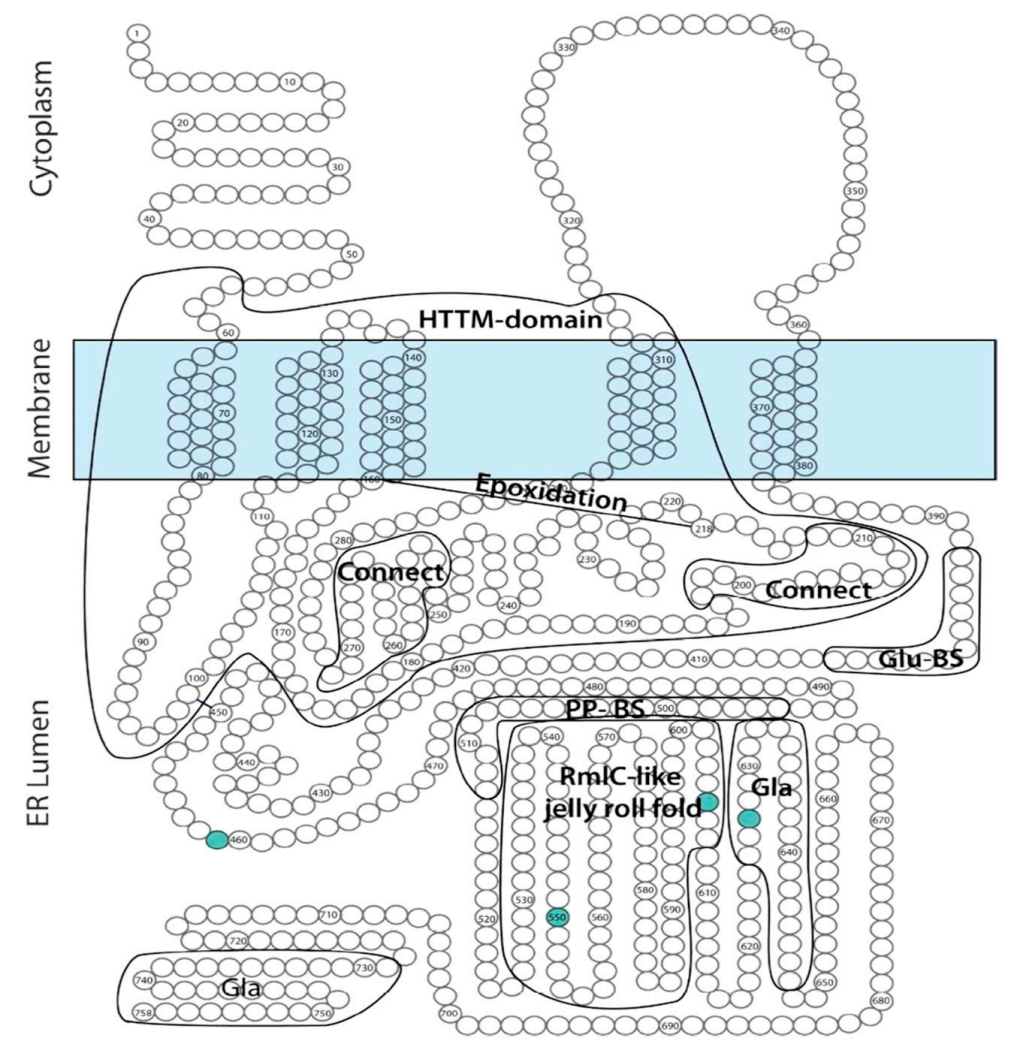

Figure 2. Predicted gamma-glutamyl carboxylase (GGCX) topology. Adapted from [9]. This figure gives an overview of the predicted localization of known or predicted GGCX domains on a GGCX topology model. Green circles depict amino acid residues which undergo glycosylation. Connect: hydrophobic domains important for interaction with vitamin K. ER: endoplasmic reticulum; HTTM: horizontally transferred transmembrane domain; Gla: gamma-carboxyglutamate; Glu-BS: glutamate binding site; PP-BS: propeptide binding site; RmlC: deoxythymidine-6-deoxy-D-xylo-4-hexulose 3,5 epimerase (EC5.1.3.13). 
In 1998, GGCX mutations were first linked to human disease by Brenner et al. in four patients with a combined deficiency of all VK-dependent blood coagulation factors (factor II, VII, IX, X and ProS and protein $C$ ) due to a homozygous missense mutation in the GGCX gene [13]. The disease was coined VK-dependent clotting factor deficiency-1 (VKCFD1, OMIM\#277450), an autosomal recessive disorder, characterized by a mild to severe bleeding tendency and a moderate predisposition to thrombotic events $[13,20]$. VKCFD1 was shown to be associated with skeletal (midfacial hypoplasia, reduced bone mass, chondrodysplasia punctata) or cardiac abnormalities (patent ductus arteriosus Botalli, septal closure defects) in some patients [13,21-30]. Next to VKCFD1, a second autosomal recessive coagulation factor deficiency exists, VKCFD2 (OMIM\#607473), caused by VKORC1 (vitamin K epoxide reductase complex, subunit 1 ; OMIM ${ }^{*} 608547$ ) mutations and is also characterized by a deficiency of all VK-dependent clotting factors. In contrast to VKCFD1, this general deficiency can usually be reversed completely using low doses of VK (ca. 5-10 mg/week) [31,32]. Skeletal abnormalities (in particular osteoporosis) have been described in VKCFD2 patients [33], but no cardiac involvement has been identified yet.

More recently, biallelic GGCX mutations were shown to cause a phenotype characterized by not only VKCFD1 but also elastic fiber (EF) mineralization and fragmentation, leading to loss of skin elasticity and loosening of the skin with a cutis laxa appearance. In the original seven patients, the phenotype was demonstrated to be similar to but more severe than the skin features in pseudoxanthoma elasticum (PXE; OMIM\#264800), an autosomal recessive ectopic mineralization disorder. The disease was therefore called PXE-like disorder with combined coagulation factor deficiency (OMIM\#610842). Classic PXE is caused by EF mineralization in soft tissues due to biallelic ABCC6 (ATP-binding cassette, subfamily C, member 6; OMIM*603234) mutations and features yellowish skin papules and plaques in flexural areas (although in more severe cases an increase in skin laxity may occur), ophthalmological symptoms (asymptomatic peau d'orange and angioid streaks and in more advanced stages subretinal neovascularization, bleeding and scarring leading to legal blindness when untreated) and cardiovascular symptoms (peripheral artery disease, cardiac diastolic dysfunction) (Figure 3A) [34,35]. Strikingly, at first the seven patients with the PXE-like syndrome had typical dermal EF calcifications leading to yellowish papules but later progressively developed excessive skin folds, not only confined to flexural areas (Figure 3B) [36]. In contrast to PXE, cardiovascular symptoms were absent and the retinopathy much milder, with mainly asymptomatic lesions (peau d'orange and angioid streaks) [36]. Since the original report, additional patients have been identified with a similar phenotype [21,37].

In 2011, we described a patient with a phenotype intermediate to PXE and the PXE-like syndrome (Figure 3C). This boy had developed excessive skin folds, typical for the PXE-like syndrome, around the age of 10, which at first were confined to the abdomen, but later progressively affected the axillae, upper arms and elbows. Prior to the development of the skin folds, the skin had appeared to have an inflamed, reddish aspect, but the skin aspect was not suggestive for an acquired post-inflammatory form of cutis laxa [38]. Upon clinical inspection, a very mild yellowish reticular rash, typical for PXE, was identified in the frontal neck. Further clinical workup included fundoscopic imaging, which revealed peau d'orange and angioid streaks, abdominal ultrasound showing renal microcalcifications, and normal coagulation tests (normal activated partial thromboplastin time (aPTT) and prothrombin time (PT)). Moreover, histological, biochemical and immunohistochemical characteristics were intermediate to PXE and the PXE-like syndrome. This patient was identified with compound heterozygous ABCC6 mutations as well as a functional single nucleotide polymorphism (SNP) in the GGCX gene [39].

In 2014, Kariminejad et al. described 14 patients from two unrelated families with a PXE-like skin phenotype (cutis laxa) and a pigmentary retinopathy, caused by biallelic mutations in the GGCX gene (Figure 3D). These patients all developed progressive vision loss with night blindness in early childhood and yellowish skin papules on the back, the lateral sides of the neck, the chest and the flexural body areas between the ages of 11 and 25 as well as an unusually loose skin on the trunk, which gradually worsened and in later stages also affected the upper limbs. Ophthalmological workup, 
including an electroretinogram, identified non-detectable rod responses or rod responses with reduced amplitude and prolonged implicit time, compatible with a pigmentary retinopathy, but failed to show any PXE-related eye symptoms (such as angioid streaks, peau d'orange or subretinal hemorrhage). A similar phenotype was seen in all affected patients, varying only in time of onset of the eye and skin symptoms. An echocardiography showed no abnormalities. Interestingly, none of these patients had VKCFD1 [40].
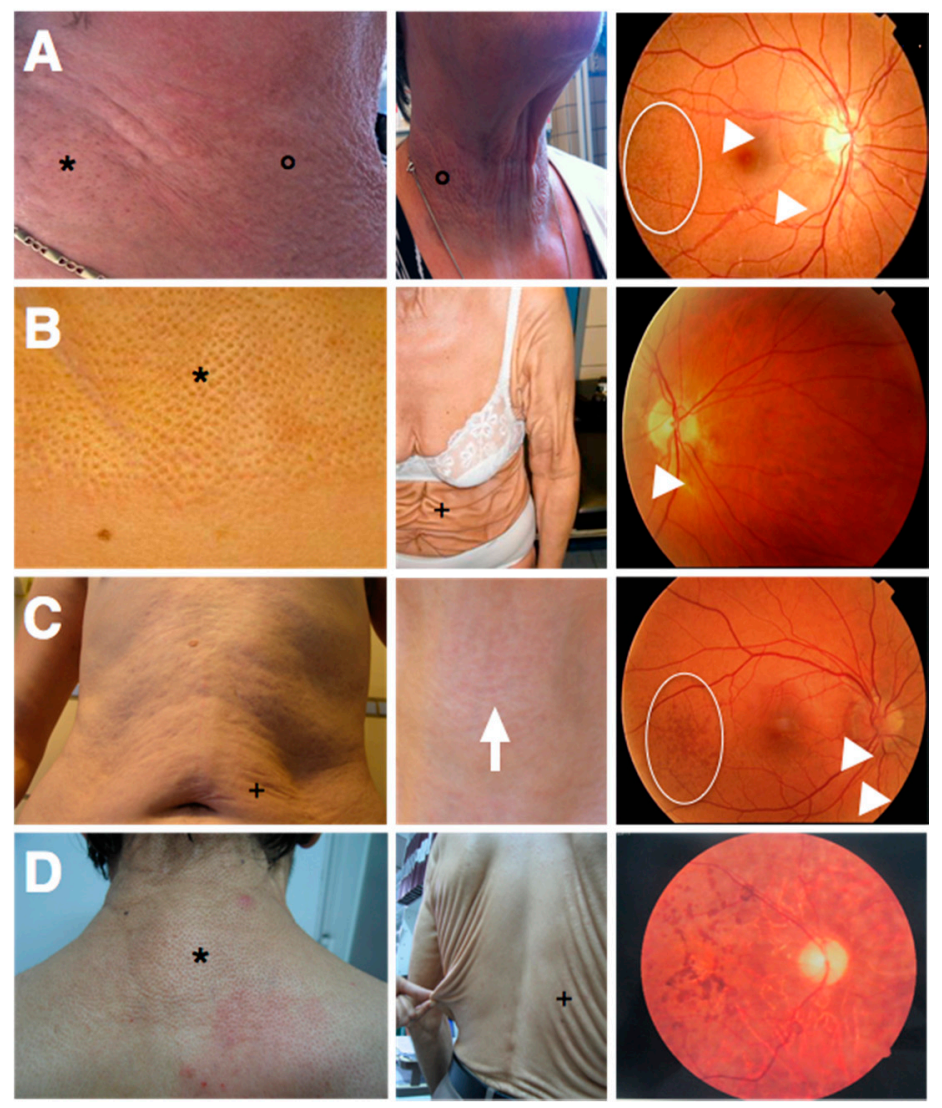

Figure 3. Skin and eye symptoms of the known gamma-glutamyl carboxylase (GGCX)-related disease entities. In each panel, two photos depict different aspects of the respective skin phenotypes (left and middle), the right image shows a fundus typical for the disease entity: (A) PXE; (B) PXE-like disorder with combined coagulation factor deficiency; (C) patient with PXE/PXE-like overlap; and (D) PXE-like syndrome with pigmentary retinopathy. *: yellowish skin papules, ${ }^{\circ}$ : skin plaques; arrowheads: angioid streaks; spherical diagram: peau d'orange; +: skin loosening and excessive skin folds; arrow: reticular rash; PXE: pseudoxanthoma elasticum; PXE-like: PXE-like disorder with combined coagulation factor deficiency.

Next to the presence of phenotypes caused by mutations in the GGCX gene, the modifying effect of GGCX variants on the response to warfarin treatment (amongst others on dose and time in therapeutic range) has been suggested repeatedly in the past and has been extensively studied. However, the results of these association studies are ambiguous, seem to be population-dependent and cannot be seen separately from variants in other genes, relevant for warfarin metabolism. Hence, the effects of these GGCX variants fall beyond the scope of this systematic review [41-44].

The variability of the GGCX-related phenotypes, as illustrated above and in Table 1, is striking while their correlation with the underlying genotypes has to date remained unclear. Therefore, we explored the possibility of genotype-phenotype correlations between GGCX mutations and the different GGCX-related diseases. 
Table 1. Overview of the phenotypic features of the known gamma-glutamyl carboxylase (GGCX)-related disease entities.

\begin{tabular}{|c|c|c|c|c|c|c|}
\hline Disease & $\begin{array}{c}\text { Coagulation } \\
\text { Deficit }\end{array}$ & Bone & Cardiac & Skin & Ocular & Other \\
\hline VKCFD1 & yes & $\begin{array}{l}\text { If present: midfacial } \\
\text { hypoplasia; reduced bone } \\
\text { mass; chondrodysplasia; } \\
\text { punctate (most frequent) }\end{array}$ & $\begin{array}{l}\text { If present: PDA; SCD } \\
\text { (most frequent) }\end{array}$ & no & no & no \\
\hline PXE-like & yes & no & no & $\begin{array}{l}\text { yellowish skin papules; skin } \\
\text { elasticity loss; skin loosening } \\
\text { (resembling cutis laxa) }\end{array}$ & peau d'orange; angioid streaks & no \\
\hline PXE/PXE-like & no & no & no & $\begin{array}{l}\text { reddish rash; excessive skin } \\
\text { folds; mild yellowish rash }\end{array}$ & peau d'orange; angioid streaks & $\begin{array}{c}\text { abdominal } \\
\text { calcifications }\end{array}$ \\
\hline $\mathrm{PXE}+\mathrm{PR}$ & no & no & no & $\begin{array}{l}\text { yellowish skin papules; loss of } \\
\text { skin elasticity; skin loosening } \\
\text { (resembling cutis laxa) }\end{array}$ & $\begin{array}{l}\text { pigmentary retinopathy: rod } \\
\text { responses non-detectable or } \\
\text { reduced amplitude; prolonged } \\
\text { implicit time }\end{array}$ & no \\
\hline
\end{tabular}

PDA: persistent ductus arteriosus Botalli; PR: pigmentary retinopathy; PXE: pseudoxanthoma elasticum; PXE-like: PXE-like disorder with combined coagulation factor deficiency; SCD: septal closure defects; VKCFD1: vitamin K-dependent clotting factor deficiency-1. 


\section{Results}

\subsection{Article Selection}

Fifty-three articles were identified through a systematic Pubmed search of which 37 did not meet the inclusion criteria: 25 papers described basic research (GGCX, gamma-carboxylation and VKDP mechanisms of action; GGCX protein structure and function determination); five articles described in vivo GGCX knockout models; three papers mentioned no relevant phenotypes; and four assessed genotype-induced variability on warfarin dosing. Further, three papers, all meeting the inclusion criteria, were manually added through reference scanning of the included papers from the Pubmed search. In total 19 papers were included for this systematic review. The selection process followed the Preferred Reporting Items for Systematic Reviews and Meta-Analysis Protocols (PRISMA-P) and is shown in Figure 4 [45]. An overview of all reviewed publications can be found in Table S2.

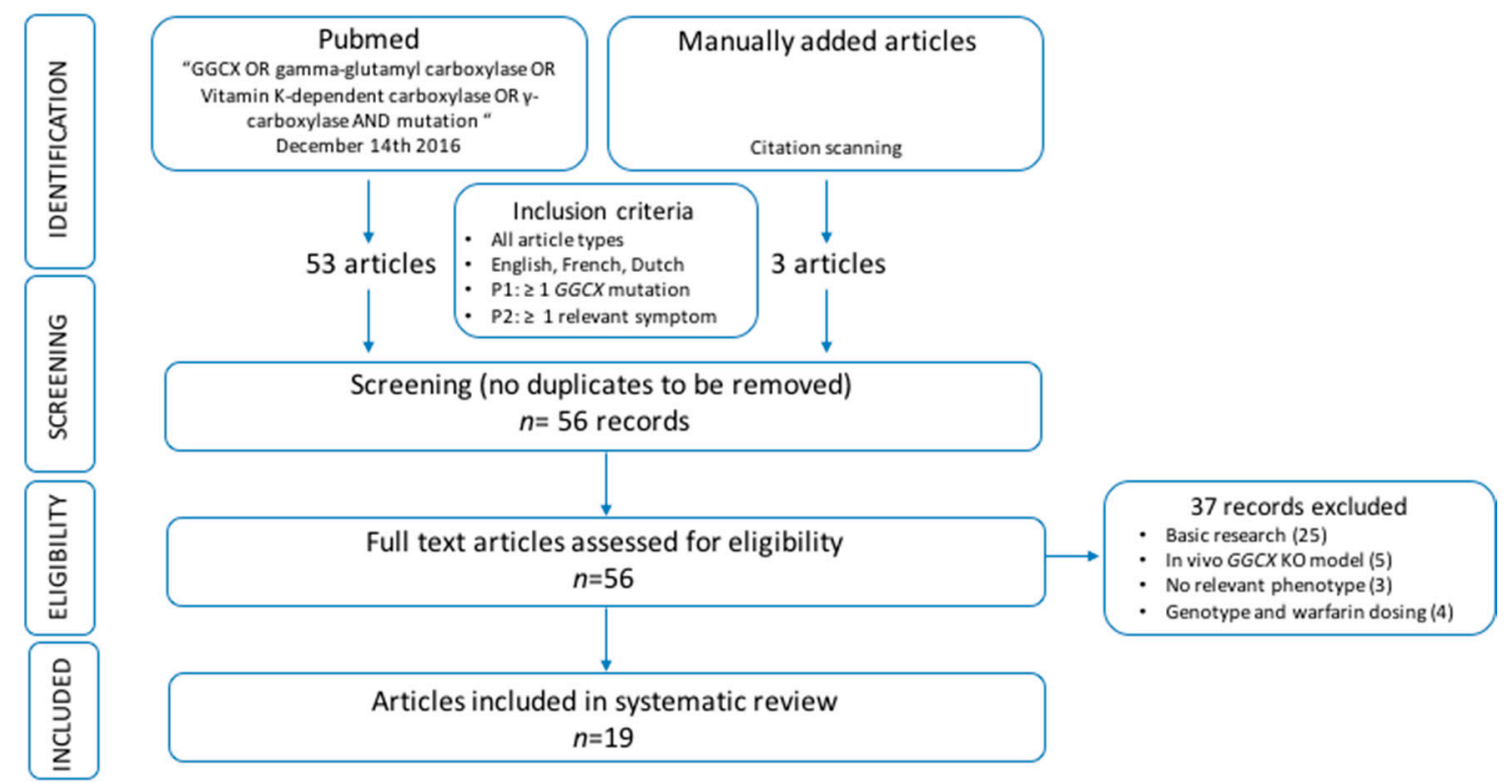

Figure 4. Overview of the pipeline used for the systematic search of the literature. GGCX: gamma-glutamyl carboxylase, KO: knockout, $n$ : number, P1: first patient criterium, P2: second patient criterium.

\subsection{Patient Data Extraction}

Fifty individual patients with at least one GGCX mutation and minimally one relevant GGCX-related phenotype were withheld from the included papers. Among these, three patients with one GGCX mutation and mono- or biallelic ABCC6 mutations were excluded from the analysis because in these patients the dermatological phenotype cannot be analyzed unambiguously, as both ABCC6 and GGCX mutations may lead to skin symptoms belonging to the same spectrum [37,46]. Thus, 47 patients were withheld for the analysis (P1-P47; Table 2), encompassing 28 individual probands (P1, P5, P7, P8, P10, P12-P23, P25-P30, P36, P41, P44, P46, P47). Nine patients were described twice in literature (patients 10 and 11 by Goldsmith et al. and Li et al.; patient 13 by Rost et al. in 2004 and 2006; patients 16-20 by Vanakker et al. in 2007 and Watzka et al. in 2014; patient 21 by Rost et al. and Watzka et al.) [21,23,36,47-49]. Patient characteristics (age, sex, ethnicity and age of first symptoms) of the 47 patients included in the analysis can be found in Table 2. 
Table 2. Patient characteristics. This table gives an overview of all the patients included in this systematic review. For each patient the GGCX mutations are mentioned (cDNA and protein annotation) as well as the protein domain in which the affected amino acid is situated. Further, for each patient, the age, nationality/ethnicity and sex are provided.

\begin{tabular}{|c|c|c|c|c|c|c|c|c|c|c|c|}
\hline \multirow[b]{2}{*}{ Id } & \multirow{2}{*}{$\begin{array}{l}\text { Original } \\
\text { Id }\end{array}$} & \multicolumn{3}{|c|}{ Allele 1} & \multicolumn{3}{|c|}{ Allele 2} & \multirow[b]{2}{*}{ Age * } & \multirow{2}{*}{$\begin{array}{l}\text { Nationality/ } \\
\text { Ethnicity }\end{array}$} & \multirow[b]{2}{*}{ Sex } & \multirow[b]{2}{*}{ References } \\
\hline & & c.Annotation & p.Annotation & $\begin{array}{l}\text { Protein } \\
\text { Domain }\end{array}$ & c.Annotation & p.Annotation & Protein Domain & & & & \\
\hline 1 & no. 20 & c. $1181 \mathrm{~T}>\mathrm{G}$ & p.(L394R) & Glu-BS & c. $1181 \mathrm{~T}>\mathrm{G}$ & p.(L394R) & Glu-BS & $\mathrm{NP} / 14$ & Arabic & $\mathrm{F}$ & $\begin{array}{l}\text { Brenner et al., } \\
1998 \text { [13] }\end{array}$ \\
\hline 2 & no. 21 & c. $1181 \mathrm{~T}>\mathrm{G}$ & p.(L394R) & Glu-BS & c. $1181 \mathrm{~T}>\mathrm{G}$ & p.(L394R) & Glu-BS & $5 \mathrm{~m} / 7$ & Arabic & $\mathrm{F}$ & $\begin{array}{l}\text { Brenner et al., } \\
\quad 1998 \text { [13] }\end{array}$ \\
\hline 3 & no. 22 & c. $1181 \mathrm{~T}>\mathrm{G}$ & p.(L394R) & Glu-BS & c. $1181 \mathrm{~T}>\mathrm{G}$ & p.(L394R) & Glu-BS & $\mathrm{NP} / 30$ & Arabic & M & $\begin{array}{c}\text { Brenner et al., } \\
1998 \text { [13] }\end{array}$ \\
\hline 4 & no. 23 & c. $1181 \mathrm{~T}>\mathrm{G}$ & p.(L394R) & Glu-BS & c. $1181 \mathrm{~T}>\mathrm{G}$ & p.(L394R) & Glu-BS & $\mathrm{NP} / 30$ & Arabic & $\mathrm{F}$ & $\begin{array}{c}\text { Brenner et al., } \\
1998 \text { [13] }\end{array}$ \\
\hline 5 & proposita & c. $469 \mathrm{~T}>\mathrm{C}$ & p.(W157R) & HTTM (TMD3) & c. $1772 \mathrm{C}>\mathrm{A}$ & p.(T591K) & RmlC-like & $2 / 11$ & Tunisian & $\mathrm{F}$ & $\begin{array}{l}\text { Dargouth et al., } \\
2006 \text { [24] }\end{array}$ \\
\hline 6 & brothers & c. $469 \mathrm{~T}>\mathrm{C}$ & p.(W157R) & HTTM (TMD3) & c. $1772 \mathrm{C}>\mathrm{A}$ & p.(T591K) & RmlC-like & 1 & Tunisian & M & $\begin{array}{l}\text { Dargouth et al., } \\
2006 \text { [24] }\end{array}$ \\
\hline 7 & patient & c. $458 \mathrm{~A}>\mathrm{G}$ & p.(D153G) & HTTM (TMD3) & c. $521 \mathrm{~T}>\mathrm{G}$ & p.(M174R) & HTTM & $4 \mathrm{~m}$ & nd & $\mathrm{F}$ & $\begin{array}{l}\text { Tie et al., } \\
2016[28]\end{array}$ \\
\hline 8 & III-3 & c. $763 \mathrm{G}>\mathrm{A}$ & p.(V255M) & HTTM & c. $899 \mathrm{C}>\mathrm{T}$ & p.(S300F) & HTTM (TMD4) & 16 & Caucasian & $\mathrm{F}$ & Li et al., 2009 [37] \\
\hline 9 & III-1 & c. $763 \mathrm{G}>\mathrm{A}$ & p.(V255M) & HTTM & c. $899 \mathrm{C}>\mathrm{T}$ & p.(S300F) & HTTM (TMD4) & 19 & Caucasian & $\mathrm{F}$ & Li et al., 2009 [37] \\
\hline 10 & $\begin{array}{l}\text { A.B. [39], } \\
\text { II-2 [40] }\end{array}$ & c. $274 \mathrm{C}>\mathrm{T}$ & p.(R83W) & HTTM & c. $1120 \mathrm{C}>\mathrm{T}$ & p.(Q374X) & TMD5 & $13 / 48$ & Caucasian & $\mathrm{F}$ & $\begin{array}{c}\text { Goldsmith et al., } \\
1982 \text { [47], } \\
\text { Li et al., 2009 [48] }\end{array}$ \\
\hline 11 & $\begin{array}{l}\text { M.F. [39], } \\
\text { II-3 [40] }\end{array}$ & c. $274 \mathrm{C}>\mathrm{T}$ & p.(R83W) & HTTM & c. $1120 \mathrm{C}>\mathrm{T}$ & p.(Q374X) & TMD5 & $18 / 46$ & Caucasian & M & $\begin{array}{c}\text { Goldsmith et al., } \\
1982 \text { [47], } \\
\text { Li et al., 2009 [48] }\end{array}$ \\
\hline 12 & patient & c. $521 \mathrm{~T}>\mathrm{G}$ & p.(M174R) & HTTM & c. $1595 \mathrm{~T}>\mathrm{C}$ & p.(I532T) & RmlC-like & 18 & Italian & M & $\begin{array}{l}\text { Lunghi et al., } \\
2011 \text { [26] }\end{array}$ \\
\hline 13 & $\mathrm{~A}$ & c. $215-1 \mathrm{G}>\mathrm{T}$ & p.(G72_L124del) & $\begin{array}{c}\text { HTTM } \\
\text { (TMD1 and -2) }\end{array}$ & c. $1454 \mathrm{G}>\mathrm{C}$ & p.(R485P) & near PP-BS & 1 & German & M & $\begin{array}{l}\text { Rost et al., } 2004 \\
\text { [23], Rost et al., } \\
2006 \text { [49] }\end{array}$ \\
\hline
\end{tabular}


Table 2. Cont.

\begin{tabular}{|c|c|c|c|c|c|c|c|c|c|c|c|}
\hline \multirow[b]{2}{*}{ Id } & \multirow{2}{*}{$\begin{array}{l}\text { Original } \\
\text { Id }\end{array}$} & \multicolumn{3}{|c|}{ Allele 1} & \multicolumn{3}{|c|}{ Allele 2} & \multirow[b]{2}{*}{ Age * } & \multirow{2}{*}{$\begin{array}{l}\text { Nationality/ } \\
\text { Ethnicity }\end{array}$} & \multirow[b]{2}{*}{ Sex } & \multirow[b]{2}{*}{ References } \\
\hline & & c.Annotation & p.Annotation & $\begin{array}{l}\text { Protein } \\
\text { Domain }\end{array}$ & c.Annotation & p.Annotation & Protein Domain & & & & \\
\hline 14 & pt 4 & c. $1502 \mathrm{G}>\mathrm{C}$ & p.(W501S) & PP-BS & c. $1502 \mathrm{G}>\mathrm{C}$ & p.(W501S) & PP-BS & $7 d$ & Lebanese & $\mathrm{M}$ & $\begin{array}{l}\text { Spronk et al., } \\
2000[22]\end{array}$ \\
\hline 15 & patient & c. $214+1 G>T$ & Splice & HTTM (TMD1) & c. $1609+3 A>G$ & Splice & $\begin{array}{l}\text { near PP-BS + } \\
\text { RmlC-like }\end{array}$ & birth/6 & Mexican & M & $\begin{array}{l}\text { Titapiwatanakun } \\
\text { et al., } 2009 \text { [25] }\end{array}$ \\
\hline 16 & pt 1 & c. $1478 \mathrm{G}>\mathrm{C}$ & p.(W493S) & near PP-BS & c. $1478 \mathrm{G}>\mathrm{C}$ & p.(W493S) & near PP-BS & 46 & Caucasian & $\mathrm{F}$ & $\begin{array}{c}\text { Vanakker et al., } \\
2007 \text { [36], } \\
\text { Watzka et al., } \\
2014 \text { [21] }\end{array}$ \\
\hline 17 & pt 3 & c. $1426 \mathrm{C}>\mathrm{T}$ & p.(R476C) & near PP-BS & - & - & - & 67 & Caucasian & $\mathrm{F}$ & $\begin{array}{c}\text { Vanakker et al., } \\
2007 \text { [36], } \\
\text { Watzka et al., } \\
2014 \text { [21] }\end{array}$ \\
\hline 18 & pt 4 & c. $1427 \mathrm{G}>\mathrm{A}$ & p. $(\mathrm{R} 476 \mathrm{H})$ & near PP-BS & - & - & - & 32 & Caucasian & $\mathrm{F}$ & $\begin{array}{c}\text { Vanakker et al., } \\
2007 \text { [36], } \\
\text { Watzka et al., } \\
2014 \text { [21] }\end{array}$ \\
\hline 19 & pt 5 & c. $1120 \mathrm{C}>\mathrm{T}$ & p.(Q374X) & TMD5 & c. $1610 \mathrm{G}>\mathrm{C}$ & p.(G537A) & RmlC-like & 46 & Caucasian & $\mathrm{F}$ & $\begin{array}{c}\text { Vanakker et al., } \\
2007 \text { [36], } \\
\text { Watzka et al., } \\
2014 \text { [21] }\end{array}$ \\
\hline 20 & pt 6 & c. $1120 \mathrm{C}>\mathrm{T}$ & p.(Q374X) & TMD5 & c. $1610 G>C$ & p.(G537A) & RmlC-like & 44 & Caucasian & $\mathrm{M}$ & $\begin{array}{c}\text { Vanakker et al., } \\
2007 \text { [36], } \\
\text { Watzka et al., } \\
2014 \text { [21] }\end{array}$ \\
\hline 21 & $\begin{array}{l}\text { B [41], } \\
\text { A [19] }\end{array}$ & c. $1211 \mathrm{~A}>\mathrm{C}$ & p.(H404P) & Glu-BS & c. $1454 \mathrm{G}>\mathrm{C}$ & p.(R485P) & near PP-BS & $22 / 38$ & German & $\mathrm{F}$ & $\begin{array}{c}\text { Rost et al., } 2006 \\
\text { [49], Watzka } \\
\text { et al., 2014 [21] }\end{array}$ \\
\hline 22 & B & c. $944 \mathrm{G}>\mathrm{A}$ & p.(W315X) & HTTM & c. $1454 \mathrm{G}>\mathrm{C}$ & p.(R485P) & near PP-BS & $14 / 20$ & German & $\mathrm{F}$ & $\begin{array}{c}\text { Watzka et al., } \\
2014 \text { [21] }\end{array}$ \\
\hline 23 & $\mathrm{C} 1$ & c. $610 \mathrm{C}>\mathrm{T}$ & p.(R204C) & HTTM & c. $610 \mathrm{C}>\mathrm{T}$ & p.(R204C) & HTTM & $2 \mathrm{~d} / 11$ & $\begin{array}{c}\text { former } \\
\text { Yugoslavia }\end{array}$ & $\mathrm{F}$ & $\begin{array}{c}\text { Watzka et al., } \\
2014 \text { [21] }\end{array}$ \\
\hline
\end{tabular}


Table 2. Cont.

\begin{tabular}{|c|c|c|c|c|c|c|c|c|c|c|c|}
\hline \multirow[b]{2}{*}{ Id } & \multirow[b]{2}{*}{$\begin{array}{l}\text { Original } \\
\text { Id }\end{array}$} & \multicolumn{3}{|c|}{ Allele 1} & \multicolumn{3}{|c|}{ Allele 2} & \multirow[b]{2}{*}{ Age * } & \multirow{2}{*}{$\begin{array}{l}\text { Nationality/ } \\
\text { Ethnicity }\end{array}$} & \multirow[b]{2}{*}{ Sex } & \multirow[b]{2}{*}{ References } \\
\hline & & c.Annotation & p.Annotation & $\begin{array}{l}\text { Protein } \\
\text { Domain }\end{array}$ & c.Annotation & p.Annotation & Protein Domain & & & & \\
\hline 24 & $\mathrm{C} 2$ & c. $610 \mathrm{C}>\mathrm{T}$ & p.(R204C) & HTTM & c. $610 \mathrm{C}>\mathrm{T}$ & p.(R204C) & HTTM & $10 / 14$ & $\begin{array}{c}\text { former } \\
\text { Yugoslavia }\end{array}$ & F & $\begin{array}{l}\text { Watzka et al., } \\
2014 \text { [21] }\end{array}$ \\
\hline 25 & $\mathrm{D}$ & c. $248 \mathrm{G}>\mathrm{T}$ & p.(R83P) & HTTM & c. $248 \mathrm{G}>\mathrm{T}$ & p.(R83P) & HTTM & $1 / 3$ & Turkish & $\mathrm{F}$ & $\begin{array}{l}\text { Watzka et al., } \\
2014 \text { [21] }\end{array}$ \\
\hline 26 & $\mathrm{E}$ & c. $610 \mathrm{C}>\mathrm{T}$ & p.(R204C) & HTTM & c. $610 \mathrm{C}>\mathrm{T}$ & p.(R204C) & HTTM & $2 \mathrm{~m} / 4$ & Turkish & M & $\begin{array}{l}\text { Watzka et al., } \\
2014 \text { [21] }\end{array}$ \\
\hline 27 & $\mathrm{~F}$ & c. $469 \mathrm{~T}>\mathrm{C}$ & p.(W157R) & HTTM (TMD3) & c.2085-5T>C & Splice & near Gla domain & $12 / 14$ & Italian & $\mathrm{F}$ & $\begin{array}{c}\text { Watzka et al., } \\
2014 \text { [21]] }\end{array}$ \\
\hline 28 & G & c. $850 \mathrm{~T}>\mathrm{C}$ & p.(S284P) & HTTM & c. $944 \mathrm{G}>\mathrm{A}$ & p.(W315X) & HTTM & $11 / 13$ & German & F & $\begin{array}{l}\text { Watzka et al., } \\
2014 \text { [21] }\end{array}$ \\
\hline 29 & $\mathrm{H}$ & c. $373 \mathrm{G}>\mathrm{A}$ & p.(G125R) & HTTM (TMD2) & c. $1601 \mathrm{~A}>\mathrm{T}$ & p.(D534V) & $\begin{array}{c}\text { near } \\
\text { PP-BS+RmlC-like }\end{array}$ & $5 \mathrm{~m} / 5$ & $\begin{array}{l}\text { German- } \\
\text { Tunisian }\end{array}$ & M & $\begin{array}{c}\text { Watzka et al., } \\
2014 \text { [21] }\end{array}$ \\
\hline 30 & patient & c. $1502 \mathrm{G}>\mathrm{C}$ & p.(W501S) & PP-BS & c. $1502 \mathrm{G}>\mathrm{C}$ & p.(W501S) & PP-BS & $3 d / 3,5$ & Lebanese & $\mathrm{F}$ & $\begin{array}{l}\text { Moussalem et al., } \\
2001 \text { [50] }\end{array}$ \\
\hline 31 & V4 & c. $373+3 \mathrm{G}>\mathrm{T}$ & p.(F74_G125del) & $\begin{array}{c}\text { HTTM } \\
\text { (TMD1 and -2) } \\
\end{array}$ & c. $373+3 \mathrm{G}>\mathrm{T}$ & p.(F74_G125del) & $\begin{array}{c}\text { HTTM } \\
\text { (TMD1 and -2) } \\
\end{array}$ & $11 / 40$ & Iranian & $\mathrm{F}$ & $\begin{array}{c}\text { Kariminejad } \\
\text { et al., } 2014 \text { [40] }\end{array}$ \\
\hline 32 & V6 & c. $373+3 \mathrm{G}>\mathrm{T}$ & p.(F74_G125del) & $\begin{array}{c}\text { HTTM } \\
\text { (TMD1 and -2) } \\
\end{array}$ & c. $373+3 G>T$ & p.(F74_G125del) & $\begin{array}{c}\text { HTTM } \\
\text { (TMD1 and -2) } \\
\end{array}$ & $12 / 52$ & Iranian & M & $\begin{array}{c}\text { Kariminejad } \\
\text { et al., } 2014 \text { [40] }\end{array}$ \\
\hline 33 & V7 & c.373+3G>T & p.(F74_G125del) & $\begin{array}{c}\text { HTTM } \\
\text { (TMD1 and -2) }\end{array}$ & c.373+3G>T & p.(F74_G125del) & $\begin{array}{c}\text { HTTM } \\
\text { (TMD1 and -2) }\end{array}$ & $12 / 37$ & Iranian & M & $\begin{array}{l}\text { Kariminejad } \\
\text { et al., } 2014 \text { [40] }\end{array}$ \\
\hline 34 & V10 & c. $373+3 G>T$ & p.(F74_G125del) & $\begin{array}{c}\text { HTTM } \\
\text { (TMD1 and -2) }\end{array}$ & c.373+3G>T & p.(F74_G125del) & $\begin{array}{c}\text { HTTM } \\
\text { (TMD1 and -2) }\end{array}$ & $25 / 48$ & Iranian & F & $\begin{array}{l}\text { Kariminejad } \\
\text { et al., } 2014 \text { [40] }\end{array}$ \\
\hline 35 & V11 & c. $373+3 G>T$ & p.(F74_G125del) & $\begin{array}{c}\text { HTTM } \\
\text { (TMD1 and -2) }\end{array}$ & c.373+3G>T & p.(F74_G125del) & $\begin{array}{c}\text { HTTM } \\
\text { (TMD1 and -2) }\end{array}$ & $14 / 40$ & Iranian & $\mathrm{F}$ & $\begin{array}{l}\text { Kariminejad } \\
\text { et al., } 2014 \text { [40] }\end{array}$ \\
\hline 36 & V12 & c. $373+3 \mathrm{G}>\mathrm{T}$ & p.(F74_G125del) & $\begin{array}{c}\text { HTTM } \\
\text { (TMD1 and -2) }\end{array}$ & c.373+3G>T & p.(F74_G125del) & $\begin{array}{c}\text { HTTM } \\
\text { (TMD1 and -2) }\end{array}$ & $12 / 34$ & Iranian & M & $\begin{array}{l}\text { Kariminejad } \\
\text { et al., } 2014 \text { [40] }\end{array}$ \\
\hline 37 & V14 & c. $373+3 G>T$ & p.(F74_G125del) & $\begin{array}{c}\text { HTTM } \\
\text { (TMD1 and -2) }\end{array}$ & c. $373+3 G>T$ & p.(F74_G125del) & $\begin{array}{c}\text { HTTM } \\
\text { (TMD1 and -2) }\end{array}$ & $14 / 16$ & Iranian & F & $\begin{array}{l}\text { Kariminejad } \\
\text { et al., 2014 [40] }\end{array}$ \\
\hline
\end{tabular}


Table 2. Cont

\begin{tabular}{|c|c|c|c|c|c|c|c|c|c|c|c|}
\hline \multirow[b]{2}{*}{ Id } & \multirow{2}{*}{$\begin{array}{l}\text { Original } \\
\text { Id }\end{array}$} & \multicolumn{3}{|c|}{ Allele 1} & \multicolumn{3}{|c|}{ Allele 2} & \multirow[b]{2}{*}{ Age * } & \multirow{2}{*}{$\begin{array}{l}\text { Nationality/ } \\
\text { Ethnicity }\end{array}$} & \multirow[b]{2}{*}{ Sex } & \multirow[b]{2}{*}{ References } \\
\hline & & c.Annotation & p.Annotation & $\begin{array}{l}\text { Protein } \\
\text { Domain }\end{array}$ & c.Annotation & p.Annotation & Protein Domain & & & & \\
\hline 38 & V16 & c. $373+3 \mathrm{G}>\mathrm{T}$ & p.(F74_G125del) & $\begin{array}{c}\text { HTTM } \\
\text { (TMD1 and -2) } \\
\end{array}$ & c. $373+3 \mathrm{G}>\mathrm{T}$ & p.(F74_G125del) & $\begin{array}{c}\text { HTTM } \\
\text { (TMD1 and -2) } \\
\end{array}$ & $10 / 21$ & Iranian & M & $\begin{array}{l}\text { Kariminejad } \\
\text { et al., } 2014 \text { [40] }\end{array}$ \\
\hline 39 & V17 & c. $373+3 \mathrm{G}>\mathrm{T}$ & p.(F74_G125del) & $\begin{array}{c}\text { HTTM } \\
\text { (TMD1 and -2) }\end{array}$ & c. $373+3 \mathrm{G}>\mathrm{T}$ & p.(F74_G125del) & $\begin{array}{c}\text { HTTM } \\
\text { (TMD1 and -2) }\end{array}$ & $16 / 23$ & Iranian & M & $\begin{array}{l}\text { Kariminejad } \\
\text { et al., } 2014 \text { [40] }\end{array}$ \\
\hline 40 & V18 & c. $373+3 \mathrm{G}>\mathrm{T}$ & p.(F74_G125del) & $\begin{array}{c}\text { HTTM } \\
\text { (TMD1 and -2) }\end{array}$ & c. $373+3 G>T$ & p.(F74_G125del) & $\begin{array}{c}\text { HTTM } \\
\text { (TMD1 and -2) }\end{array}$ & $11 / 29$ & Iranian & $\mathrm{M}$ & $\begin{array}{l}\text { Kariminejad } \\
\text { et al., } 2014 \text { [40] }\end{array}$ \\
\hline 41 & IV1 & c. $373+3 \mathrm{G}>\mathrm{T}$ & p.(F74_G125del) & $\begin{array}{c}\text { HTTM } \\
\text { (TMD1 and -2) }\end{array}$ & c. $373+3 \mathrm{G}>\mathrm{T}$ & p.(F74_G125del) & $\begin{array}{c}\text { HTTM } \\
\text { (TMD1 and -2) }\end{array}$ & $14 / 21$ & Iranian & M & $\begin{array}{l}\text { Kariminejad } \\
\text { et al., } 2014 \text { [40] }\end{array}$ \\
\hline 42 & IV5 & c. $373+3 G>T$ & p.(F74_G125del) & $\begin{array}{c}\text { HTTM } \\
\text { (TMD1 and -2) }\end{array}$ & c. $373+3 \mathrm{G}>\mathrm{T}$ & p.(F74_G125del) & $\begin{array}{c}\text { HTTM } \\
\text { (TMD1 and -2) }\end{array}$ & $12 / 28$ & Iranian & $\mathrm{M}$ & $\begin{array}{l}\text { Kariminejad } \\
\text { et al., } 2014 \text { [40] }\end{array}$ \\
\hline 43 & IV6 & c. $373+3 \mathrm{G}>\mathrm{T}$ & p.(F74_G125del) & $\begin{array}{c}\text { HTTM } \\
\text { (TMD1 and -2) }\end{array}$ & c. $373+3 \mathrm{G}>\mathrm{T}$ & p.(F74_G125del) & $\begin{array}{c}\text { HTTM } \\
\text { (TMD1 and -2) }\end{array}$ & $12 / 21$ & Iranian & F & $\begin{array}{l}\text { Kariminejad } \\
\text { et al., } 2014 \text { [40] }\end{array}$ \\
\hline 44 & A.K. & 14 bp del I1 & - & - & 14 bp del I1 & - & - & $3 \mathrm{~m} / 9$ & - & M & $\begin{array}{c}\text { Thomas et al., } \\
2003 \text { [27] }\end{array}$ \\
\hline 45 & D.K. & 14 bp del I1 & - & - & 14 bp del I1 & - & - & $6 / 15$ & - & $\mathrm{F}$ & $\begin{array}{c}\text { Thomas et al., } \\
2003 \text { [27] }\end{array}$ \\
\hline 46 & propositus & c. $1479 \mathrm{G}>\mathrm{T}$ & p.(W493C) & Near PP-BS & c. $2110 \mathrm{C}>\mathrm{T}$ & p.(R704X) & $\begin{array}{c}\text { Near } \\
\text { Gla-domain }\end{array}$ & Birth/1 & French & M & $\begin{array}{l}\text { Darghouth et al., } \\
2009 \text { [29] }\end{array}$ \\
\hline 47 & infant & c. $44-1 \mathrm{G}>\mathrm{A}$ & p.(D15_F71del) & $\begin{array}{c}\text { N-terminus + } \\
\text { HTTM (TMD1) }\end{array}$ & c. $44-1 \mathrm{G}>\mathrm{A}$ & p.(D15_F71del) & $\begin{array}{c}\text { N-terminus + } \\
\text { HTTM (TMD1) }\end{array}$ & $14 \mathrm{~m} / 4$ & Caucasian & M & $\begin{array}{l}\text { Dasi et al., } \\
2016 \text { [30] }\end{array}$ \\
\hline
\end{tabular}

C.annotation: cDNA-annotation; p.annotation: protein annotation; d: days; m: months (in "Age" column only); F: female (in "Sex" column only); Gla: gamma-carboxyglutamate; Glu-BS: glutamate binding site; HTTM: horizontally transferred tron grut splice sitemutation; TMD: tapide binding site; gene; * age is stated in years, unless otherwise specified; notation: age of first symptoms or of first examination/age a last follow-up. 


\subsection{Genotype Analysis}

Mutations were annotated according to transcript NM000821.6 in 12 out of 19 papers. Five publications used reference sequence BC013979, in which +1 is located at the -28 position of NM000821.6 $[22,36,37,48,50]$. Therefore, the annotation of these mutations was corrected accordingly (Table 3). The genotypes of P18 and P19 were already corrected by Watzka et al., but for one mutation, i.e., c.1339G > T, the mutation remained incorrectly annotated and was corrected in this paper $[21,36]$. Two publications used unspecified reference sequences, leading to different cDNA-annotations, but the same protein annotations; cDNA annotations were updated to reference sequence NM0000821.6.

Table 3. Update of the mutation annotation according to reference sequence NM00082. In the original articles, reference sequence BC 013979 was used (+1 located at the -28 position of NM000821).

\begin{tabular}{|c|c|c|c|}
\hline $\begin{array}{l}\text { cDNA Annotation } \\
\text { in Original Article }\end{array}$ & $\begin{array}{c}\text { Corrected cDNA } \\
\text { Annotation }\end{array}$ & Protein Annotation & Original Article \\
\hline c.791G >A & c. $763 \mathrm{G}>\mathrm{A}$ & p.(V255M) & Li et al., 2009 [37] \\
\hline c. $927 \mathrm{C}>\mathrm{T}$ & c. $899 \mathrm{C}>\mathrm{T}$ & p.(S300F) & Li et al., 2009 [37] \\
\hline c. $1148 \mathrm{C}>\mathrm{T}$ & c. $1120 \mathrm{C}>\mathrm{T}$ & p.(Q374X) & Li et al., 2009 [48] \\
\hline c. $1454 \mathrm{G}>\mathrm{C}$ & c. $1426 \mathrm{C}>\mathrm{T}$ & p. (R476C) & Vanakker et al., 2007 [36] \\
\hline c. $1455 \mathrm{G}>\mathrm{A}$ & c. $1427 \mathrm{G}>\mathrm{A}$ & p.(R476H) & Vanakker et al., 2007 [36] \\
\hline c. $1149 \mathrm{C}>\mathrm{T}$ & c. $1120 \mathrm{C}>\mathrm{T}$ & p.(Q374X) & Vanakker et al., 2007 [36] \\
\hline c. $1339 \mathrm{G}>\mathrm{T}$ & c. $1610 \mathrm{G}>\mathrm{C}$ & p.(G537A) & Vanakker et al., 2007 [36] \\
\hline c. $1530 \mathrm{G}>\mathrm{C}$ & c. $1502 \mathrm{G}>\mathrm{C}$ & p.(W501S) & Spronk et al., 2000 [22], Moussalem et al., 2001 [50] \\
\hline c. $1358+1 \mathrm{G}>\mathrm{T}$ & c. $214+1 \mathrm{G}>\mathrm{T}$ & Splice site mutation & Titapiwatanakun et al., 2009 [25] \\
\hline c. $10364+3 A>G$ & c. $1609+3 \mathrm{~A}>\mathrm{G}$ & Splice site mutation & Titapiwatanakun et al., 2009 [25] \\
\hline c. $1565 \mathrm{G}>\mathrm{T}$ & c. $1565 \mathrm{G}>\mathrm{T}$ & p.(W493C) & Darghouth et al., 2009 [29] \\
\hline c. $2196 \mathrm{C}>\mathrm{T}$ & c. $2100 \mathrm{C}>\mathrm{T}$ & p. (R704X) & Darghouth et al., 2009 [29] \\
\hline
\end{tabular}

For Darghouth et al., 2009 and Titapiwatanakun et al., 2009 the reference sequence was not mentioned.

Thirty-two different mutations were identified, 14 of which were located in the HTTM-domain (amongst others one in TMD1, two in TMD1 and -2, one in TMD2, two in TMD3 and one in TMD4), one mutation affected the N-terminal region and the first part of the HTTM-domain (TMD1), one mutation was located in TMD5, three at or near the glutamate binding site, six at or near the propeptide binding site, three mutations were found in the RmlC-like jelly roll fold, two mutations near the propeptide binding site and RmlC-like jelly roll fold and one near the most $\mathrm{C}$-terminal autocarboxylated Gla-domain. One mutation was a $14 \mathrm{bp}$ deletion in intron 1, not leading to a change at the protein level (Table 2). This mutation was proposed to influence expression of GGCX in the affected patients, as the deletion destroyed a reverse palindromic sequence (TTGAGGCAA), often associated with cis-acting elements (involved in protein expression) [27]. Interestingly, in P47, harboring a homozygous splice site mutation leading to the deletion of exon 2, paternal uniparenteral disomy was identified [30].

\subsection{Exploring Possible Genotype-Phenotype Correlations in GGCX-Related Phenotypes}

GGCX mutations were identified mainly in combination with five distinct phenotypes: ophthalmological, dermal, cardiac and osseous symptoms, and coagulation abnormalities. These phenotypes can be related to PXE (ophthalmological and dermatological symptoms), VKCFD1 or the fetal warfarin or DiSaia syndrome (cardiac, skeletal and facial abnormalities).

\subsubsection{Cardiac Phenotype}

Eight patients were reported to have congenital heart defects, i.e., a persistent ductus arteriosus Botalli (P13, and P27), septal closure defects (P5, P6, P25, P28, and P47), Wolff-Parkinson-White syndrome (P47) and a congenital supravalvular pulmonary stenosis and peripheral pulmonary artery stenosis (P8) (Table 4). Apart from P8 and P26, all patients also had facial dysmorphisms and/or skeletal features. P8, the only patient with confirmed congenital pulmonary stenosis, has a sister (P9) carrying the same GGCX genotype with no cardiac phenotype. 
Table 4. Cardiac involvement in patients with GGCX mutations. This table gives an overview of all patients in the analyzed cohort with cardiac involvement. For each patient, the GGCX mutations on both alleles and the affected protein domain are stated (protein annotation). Further, a brief overview of the cardiac symptoms is shown.

\begin{tabular}{|c|c|c|c|c|c|c|c|}
\hline \multirow[b]{2}{*}{ Id } & \multicolumn{2}{|c|}{ Allele 1} & \multicolumn{2}{|c|}{ Allele 2} & \multirow[b]{2}{*}{ SCD } & \multirow[b]{2}{*}{ PDA } & \multirow[b]{2}{*}{ Other } \\
\hline & Annotation & $\begin{array}{l}\text { Protein } \\
\text { Domain }\end{array}$ & Annotation & $\begin{array}{l}\text { Protein } \\
\text { Domain }\end{array}$ & & & \\
\hline 5 & p.(W157R) & HTTM (TMD3) & p.(T591K) & RmlC-like & $\mathrm{x}$ & & \\
\hline 6 & p.(W157R) & HTTM (TMD3) & p.(T591K) & RmlC-like & $\mathrm{x}$ & & \\
\hline 8 & p.(V255M) & HTTM & p.(S300F) & HTTM (TMD4) & & & * \\
\hline 13 & p.(G72_L124del) & $\begin{array}{c}\text { HTTM } \\
\text { (TMD1 and -2) }\end{array}$ & $\mathrm{p} .(\mathrm{R} 485 \mathrm{P})$ & near PP-BS & & $\mathrm{x}$ & \\
\hline 25 & p.(R83P) & HTTM & p.(R83P) & HTTM & $\mathrm{x}$ & & \\
\hline 27 & p.(W157R) & HTTM (TMD3) & $\begin{array}{l}\text { c.2085-5T>C } \\
\text { (splice) }\end{array}$ & $\begin{array}{c}\text { near Gla } \\
\text { domain }\end{array}$ & & $\mathrm{x}$ & \\
\hline 28 & p.(S284P) & HTTM & p.(W315X) & HTTM & $\mathrm{x}$ & & \\
\hline 47 & p.(D15_F71del) & $\begin{array}{c}\text { N-terminus + } \\
\text { HTTM (TMD1) }\end{array}$ & p.(D15_F71del) & $\begin{array}{c}\text { N-terminus + } \\
\text { HTTM (TMD1) }\end{array}$ & $x$ & & + \\
\hline
\end{tabular}

Gla: gamma-carboxyglutamate; HTTM: horizontally transferred transmembrane domain; Id: identification number; PDA: patent ductus arteriosus Botalli; PP-BS: propeptide binding site; RmlC: deoxythymidine-6-deoxyD-xylo-4-hexulose 3,5 epimerase (EC5.1.3.13); RmlC-like: RmlC-like jelly roll fold; SCD: septal closure defects; splice: splice site mutation; TMD: transmembrane domain; * congenital supravalvular pulmonary stenosis and peripheral pulmonary artery stenosis; ${ }^{+}$Wolff-Parkinson-White syndrome.

Seven different genotypes and in total 11 different GGCX mutations were identified in the eight patients with a cardiac phenotype; and 7/11 GGCX mutations were located in the HTTM domain ( 1 in TMD1 and -2, one in TMD3, and one in TMD4), one mutation affected the N-terminal region and the first part of the HTTM-domain (TMD1), one mutation was localized in the RmlC-like jelly roll fold, one near the propeptide binding site and one near the C-terminal Gla domain. The mutation p.(W157R) was identified in three patients, of whom two siblings with p.(T591K) on the other allele and one unrelated patient with c.2085-5T>C as the second mutation. The genotype p.(V255M); p.(S300F) was identified in one patient (P8) with a cardiac problem and in this patients' sibling (P9) with no cardiac abnormalities. Overall, all patients with a cardiac defect had at least one mutation in the HTTM domain.

\subsubsection{Dermatological Phenotype}

Twenty-three patients had dermatological PXE-like symptoms, i.e., yellowish papules and excessive skin folds reminiscent of cutis laxa (Table 5). Affected regions included the neck and flexural areas (amongst others the axillae), but also the trunk, groins and/or chest. The age of onset of the skin lesions was under the age of 10 in one patient, between 10 and 20 years in 17 patients, above the age of 20 in two patients and not mentioned in three adult patients with skin symptoms. Overall, in this cohort of 47 patients, 21/24 patients older than 18 years had PXE-like skin symptoms. P17 already had skin symptoms at three years of age, which became more severe during puberty.

Nine different genotypes were associated with skin symptoms, encompassing 11 different GGCX mutations. Five mutations were located in the HTTM domain, four near the propeptide binding site, one in the glutamate binding site, one in the RmlC-like jelly roll fold and one in TMD5. In P17 and P18, only one GGCX mutation could be identified. In all other patients, compound heterozygous or homozygous GGCX mutations were present. 
Table 5. GGCX-related skin manifestations in analyzed patient cohort. This table gives an overview of all patients in the analyzed cohort with skin features. For each patient, the GGCX mutations on both alleles and the affected protein domain are stated (protein annotation). Further, a brief overview of the skin symptoms is shown.

\begin{tabular}{|c|c|c|c|c|c|c|c|}
\hline \multirow[b]{2}{*}{ Id } & \multicolumn{2}{|c|}{ Allele 1} & \multicolumn{2}{|c|}{ Allele 2} & \multirow[b]{2}{*}{ CL } & \multirow[b]{2}{*}{ YP } & \multirow{2}{*}{$\begin{array}{c}\text { Age of Onset } \\
\text { (years) }\end{array}$} \\
\hline & Annotation & $\begin{array}{l}\text { Protein } \\
\text { Domain }\end{array}$ & Annotation & $\begin{array}{l}\text { Protein } \\
\text { Domain }\end{array}$ & & & \\
\hline 8 & p.(V255M) & HTTM & p.(S300F) & HTTM (TMD4) & $x$ & & 10 \\
\hline 9 & p.(V255M) & HTTM & p.(S300F) & HTTM (TMD4) & $x$ & & early teens \\
\hline 10 & p.(R83W) & HTTM & p.(Q374X) & TMD5 & $\mathrm{x}$ & $x$ & 27 \\
\hline 11 & p.(R83W) & HTTM & p.(Q374X) & TMD5 & $\mathrm{x}$ & $\mathrm{x}$ & nd \\
\hline 16 & p.(W493S) & near PP-BS & p.(W493S) & near PP-BS & $x$ & & 18 \\
\hline 17 & p.(R476C) & near PP-BS & - & - & $x$ & $x$ & 3 \\
\hline 18 & p.(R476H) & near PP-BS & - & - & $x$ & $x$ & 18 \\
\hline 19 & p.(Q374X) & TMD5 & p.(G537A) & Rmlc-like & $x$ & $x$ & - \\
\hline 20 & p.(Q374X) & TMD5 & p.(G537A) & Rmlc-like & $\mathrm{x}$ & $x$ & - \\
\hline 21 & p. $(\mathrm{H} 404 \mathrm{P})$ & Glu-BS & p. (R485P) & near PP-BS & $\mathrm{x}$ & $x$ & puberty \\
\hline 31 & p.(F74_G125del) & $\begin{array}{c}\text { HTTM } \\
\text { (TMD1 and -2) }\end{array}$ & p.(F74_G125del) & $\begin{array}{c}\text { HTTM } \\
\text { (TMD1 and -2) }\end{array}$ & $\mathrm{x}$ & $\mathrm{x}$ & 11 \\
\hline 32 & p.(F74_G125del) & $\begin{array}{c}\text { HTTM } \\
\text { (TMD1 and -2) }\end{array}$ & p.(F74_G125del) & $\begin{array}{c}\text { HTTM } \\
\text { (TMD1 and -2) }\end{array}$ & $\mathrm{x}$ & $\mathrm{x}$ & 12 \\
\hline 33 & p.(F74_G125del) & $\begin{array}{c}\text { HTTM } \\
\text { (TMD1 and -2) }\end{array}$ & p.(F74_G125del) & $\begin{array}{c}\text { HTTM } \\
\text { (TMD1 and -2) }\end{array}$ & $\mathrm{x}$ & $\mathrm{x}$ & 12 \\
\hline 34 & p.(F74_G125del) & $\begin{array}{c}\text { HTTM } \\
\text { (TMD1 and -2) }\end{array}$ & p.(F74_G125del) & $\begin{array}{c}\text { HTTM } \\
\text { (TMD1 and -2) }\end{array}$ & $\mathrm{x}$ & $\mathrm{x}$ & 25 \\
\hline 35 & p.(F74_G125del) & $\begin{array}{c}\text { HTTM } \\
\text { (TMD1 and -2) }\end{array}$ & p.(F74_G125del) & $\begin{array}{c}\text { HTTM } \\
\text { (TMD1 and -2) }\end{array}$ & $\mathrm{x}$ & $\mathrm{x}$ & 14 \\
\hline 36 & p.(F74_G125del) & $\begin{array}{c}\text { HTTM } \\
\text { (TMD1 and -2) }\end{array}$ & p.(F74_G125del) & $\begin{array}{c}\text { HTTM } \\
\text { (TMD1 and -2) }\end{array}$ & $\mathrm{x}$ & $\mathrm{x}$ & 12 \\
\hline 37 & p.(F74_G125del) & $\begin{array}{c}\text { HTTM } \\
\text { (TMD1 and -2) }\end{array}$ & p.(F74_G125del) & $\begin{array}{c}\text { HTTM } \\
\text { (TMD1 and -2) }\end{array}$ & $\mathrm{x}$ & $\mathrm{x}$ & 14 \\
\hline 38 & p.(F74_G125del) & $\begin{array}{c}\text { HTTM } \\
\text { (TMD1 and -2) }\end{array}$ & p.(F74_G125del) & $\begin{array}{c}\text { HTTM } \\
\text { (TMD1 and -2) }\end{array}$ & $\mathrm{x}$ & $\mathrm{x}$ & 10 \\
\hline 39 & p.(F74_G125del) & $\begin{array}{c}\text { HTTM } \\
\text { (TMD1 and -2) }\end{array}$ & p.(F74_G125del) & $\begin{array}{c}\text { HTTM } \\
\text { (TMD1 and -2) }\end{array}$ & $\mathrm{x}$ & $\mathrm{x}$ & 16 \\
\hline 40 & p.(F74_G125del) & $\begin{array}{c}\text { HTTM } \\
\text { (TMD1 and -2) }\end{array}$ & p.(F74_G125del) & $\begin{array}{c}\text { HTTM } \\
\text { (TMD1 and -2) }\end{array}$ & $\mathrm{x}$ & $\mathrm{x}$ & 11 \\
\hline 41 & p.(F74_G125del) & $\begin{array}{c}\text { HTTM } \\
\text { (TMD1 and -2) }\end{array}$ & p.(F74_G125del) & $\begin{array}{c}\text { HTTM } \\
\text { (TMD1 and -2) }\end{array}$ & $\mathrm{x}$ & $\mathrm{x}$ & 14 \\
\hline 42 & p.(F74_G125del) & $\begin{array}{c}\text { HTTM } \\
\text { (TMD1 and -2) }\end{array}$ & p.(F74_G125del) & $\begin{array}{c}\text { HTTM } \\
\text { (TMD1 and -2) }\end{array}$ & $\mathrm{x}$ & $\mathrm{x}$ & 12 \\
\hline 43 & p.(F74_G125del) & $\begin{array}{c}\text { HTTM } \\
\text { (TMD1 and }-2 \text { ) }\end{array}$ & p.(F74_G125del) & $\begin{array}{c}\text { HTTM } \\
\text { (TMD1 and -2) }\end{array}$ & $\mathrm{x}$ & $\mathrm{x}$ & 12 \\
\hline
\end{tabular}

CL: cutis laxa; Glu-BS: glutamate binding site; HTTM: horizontally transferred transmembrane domain; Id: identification number; PP-BS: propeptide binding site; RmlC: deoxythymidine-6-deoxy-D-xylo-4-hexulose 3,5 epimerase (EC5.1.3.13); RmlC-like: RmlC-like jelly roll fold; TMD: transmembrane domain; YP: yellow papules.

\subsubsection{Ophthalmological Phenotype}

Eighteen patients were diagnosed with ophthalmological symptoms, including isolated angioid streaks (P10, P16, and P17), angioid streaks and peau d'orange (P11, and P18) and a pigmentary retinopathy of variable severity (P31-P43) (Table 6). All 18 patients with ophthalmological symptoms also had PXE-like skin symptoms.

The eye symptoms were associated with six different genotypes comprising eight different mutations: four mutations were located in the HTTM domain, three near the propeptide binding site and one in TMD5. In three of the six genotypes associated with eye problems in this cohort, at least one mutation was located N-terminally of the propeptide binding site (i.e., p.(R476H), p.(R476C), p.(W493S)). The arginine-residue at position 476 is part of a highly conserved seven AA-long sequence (N-NDRFQQR-C) and the tryptophan-residue at position 493 is highly conserved among different species (11/11) (Table S3). The GGCX genotype p.(F73_G125del); p.(F73_G125del), leading to a homozygous deletion of exon 3 , is the only genotype that is associated with a pigmentary retinopathy 
in all affected patients (P31-P43). Interestingly, all examined patients in these families were affected by this retinopathy [40]. Another mutation with the same functional consequence was already shown in P13, being present in combination with the p.(R485P) mutation and without an ophthalmological phenotype. The exact intronic nucleotides affected by the mutation leading to this deletion are different in both cases (c.373+3G $>\mathrm{T}$ versus c. $215-1 \mathrm{G}>\mathrm{T})$.

Table 6. Eye phenotype in patients with GGCX mutations. This table gives an overview of all patients in the analyzed cohort with ophthalmological manifestations. For each patient, the GGCX mutations on both alleles and the affected protein domain are stated (protein annotation). Further, a brief overview of the eye symptoms is shown.

\begin{tabular}{|c|c|c|c|c|c|c|c|}
\hline \multirow{2}{*}{ Id } & \multicolumn{2}{|c|}{ Allele 1} & \multicolumn{2}{|c|}{ Allele 2} & \multirow{2}{*}{ AS } & \multirow{2}{*}{$\mathbf{P d}^{\prime} \mathrm{O}$} & \multirow{2}{*}{ PR } \\
\hline & Annotation & Protein Domain & Annotation & Protein Domain & & & \\
\hline 8 & p.(V255M) & HTTM & p.(S300F) & HTTM (TMD4) & & & \\
\hline 10 & p.(R83W) & HTTM & p.(Q374X) & TMD5 & $\mathrm{x}$ & & \\
\hline 11 & p.(R83W) & HTTM & p.(Q374X) & TMD5 & $\mathrm{x}$ & $\mathrm{x}$ & \\
\hline 16 & p.(W493S) & near PP-BS & p.(W493S) & near PP-BS & $\mathrm{x}$ & & \\
\hline 17 & p.(R476C) & near PP-BS & r- - & - & $\mathrm{x}$ & & \\
\hline 18 & p.(R476H) & near PP-BS & - & - & $\mathrm{x}$ & $\mathrm{x}$ & \\
\hline 31 & p.(F74_G125del) & HTTM (TMD1 and -2) & p.(F74_G125del) & HTTM (TMD1 and -2) & & & $\mathrm{x}$ \\
\hline 32 & p.(F74_G125del) & HTTM (TMD1 and -2) & p.(F74_G125del) & HTTM (TMD1 and -2) & & & $\mathrm{x}$ \\
\hline 33 & p.(F74_G125del) & HTTM (TMD1 and -2) & p.(F74_G125del) & HTTM (TMD1 and -2) & & & $\mathrm{x}$ \\
\hline 34 & p.(F74_G125del) & HTTM (TMD1 and -2) & p.(F74_G125del) & HTTM (TMD1 and -2) & & & $\mathrm{x}$ \\
\hline 35 & p.(F74_G125del) & HTTM (TMD1 and -2) & p.(F74_G125del) & HTTM (TMD1 and -2) & & & $\mathrm{x}$ \\
\hline 36 & p.(F74_G125del) & HTTM (TMD1 and -2) & p.(F74_G125del) & HTTM (TMD1 and -2) & & & $\mathrm{x}$ \\
\hline 37 & p.(F74_G125del) & HTTM (TMD1 and -2) & p.(F74_G125del) & HTTM (TMD1 and -2) & & & $x$ \\
\hline 38 & p.(F74_G125del) & HTTM (TMD1 and -2) & p.(F74_G125del) & HTTM (TMD1 and -2) & & & $\mathrm{x}$ \\
\hline 39 & p.(F74_G125del) & HTTM (TMD1 and -2) & p.(F74_G125del) & HTTM (TMD1 and -2) & & & $\mathrm{x}$ \\
\hline 40 & p.(F74_G125del) & HTTM (TMD1 and -2) & p.(F74_G125del) & HTTM (TMD1 and -2) & & & $\mathrm{x}$ \\
\hline 41 & p.(F74_G125del) & HTTM (TMD1 and -2) & p.(F74_G125del) & HTTM (TMD1 and -2) & & & $\mathrm{x}$ \\
\hline 42 & p.(F74_G125del) & HTTM (TMD1 and -2) & p.(F74_G125del) & HTTM (TMD1 and -2) & & & $\mathrm{x}$ \\
\hline 43 & p.(F74_G125del) & HTTM (TMD1 and -2) & p.(F74_G125del) & HTTM (TMD1 and -2) & & & $\mathrm{x}$ \\
\hline
\end{tabular}

AS: angioid streaks; HTTM: horizontally transferred transmembrane domain; Id: identification number; Pd'O: peau d'orange; PP-BS: propeptide binding site; PR: pigmentary retinopathy; TMD: transmembrane domain.

\subsubsection{Osseous Phenotype}

Eleven patients had facial dysmorphisms and/or a skeletal phenotype (Table 7). Facial dysmorphisms included midfacial hypoplasia with flat nasal bridge and a short nose (P5, P6, P13, P22-P24, P27, and P29). The skeletal phenotype comprised reduced bone mass (P22-24, P27, and P29), chondrodysplasia punctata (P22, and P29), stunted growth (P5, and P6), clinodactyly (P47) and brachytelephalangy of the fingers (P7). Only P22 and P29 had a full osseous phenotype, comprising facial dysmorphia, reduced bone mass and chondrodysplasia punctata. Brachytelephalangy of the fingers is a distinct characteristic of Keutel syndrome (OMIM\#245150), an autosomal recessive disorder caused by mutations in MGP, a VKDP that is carboxylated by GGCX. After biallelic GGCX mutations were identified in this patient, functional analysis showed an abolished carboxylation of MGP, which remained in the inactive state, thus mimicking part of the Keutel syndrome phenotype [28]. The same mimicry also occurred for two other patients with a skeletal phenotype: P13 at birth had facial dysmorphia similar to Williams-Beuren syndrome (OMIM\#194050) and P22 had chondrodysplasia punctata similar to Conradi-Hünermann syndrome (X-linked chondrodysplasia punctata; OMIM\#302960). None of the patients had causal genetic defects for these syndromes. Apart from the clinodactyly P47 also had ectopic calcification with nephrocalcinosis and mineralization of the trachea and bronchi.

Bone symptoms were associated with nine different genotypes and 13 different mutations, eight of which were located in the HTTM domain (two in TMD1 and -2 and two in TMD3), one mutation affected the $\mathrm{N}$-terminal region and the first part of the HTTM-domain (TMD1), one mutation was localized in the RmlC-like jelly roll fold, one near the C-terminal Gla domain and two near the propeptide binding site. In three patients (P23, P24, and P47), a homozygous genotype was identified: 
(p.(R204C); p.(R204C)) in P23 and P24 and c.44-1G>A in P47; all other patients had compound heterozygous mutations. The mutation p.(R485P), located near the propeptide binding site (cf. supra), was found twice in compound heterozygous state, respectively, with p.(G72_L124del) and p.(W315X) on the other allele; p.(W157R) was identified in three patients, respectively, with p.(T591K) (P5, P6) and c.2085-5T>C (P28) in trans. All patients with an osseous phenotype had at least 1 mutation in the HTTM domain.

Table 7. Osseous involvement in patients with GGCX mutations. This table gives an overview of all patients in the analyzed cohort with osseous manifestations features. For each patient, the GGCX mutations on both alleles and the affected protein domain are stated (protein annotation). Further, a brief overview of the bone features is shown.

\begin{tabular}{|c|c|c|c|c|c|c|c|c|}
\hline \multirow{2}{*}{ Id } & \multicolumn{2}{|c|}{ Allele 1} & \multicolumn{2}{|c|}{ Allele 2} & \multirow{2}{*}{ FD } & \multirow{2}{*}{$\mathrm{CP}$} & \multirow{2}{*}{ RBM } & \multirow{2}{*}{ Other } \\
\hline & Annotation & Protein Domain & Annotation & Protein Domain & & & & \\
\hline 5 & p.(W157R) & HTTM (TMD3) & p.(T591K) & RmlC-like & $\mathrm{x}$ & & & * \\
\hline 6 & p.(W157R) & HTTM (TMD3) & p.(T591K) & RmlC-like & & & & + \\
\hline 7 & p.(D153G) & HTTM (TMD3) & p.(M174R) & HTTM & & & & $\ddagger$ \\
\hline 13 & p.(G72_L124del) & $\begin{array}{l}\text { HTTM (TMD1 } \\
\text { and -2) }\end{array}$ & p.(R485P) & near PP-BS & $\mathrm{x}$ & & & \\
\hline 22 & p.(W315X) & HTTM & p.(R485P) & near PP-BS & $\mathrm{x}$ & $\mathrm{x}$ & $\mathrm{x}$ & \\
\hline 23 & p.(R204C) & HTTM & p.(R204C) & HTTM & $\mathrm{x}$ & & $\mathrm{x}$ & \\
\hline 24 & p.(R204C) & HTTM & p.(R204C) & HTTM & & & $x$ & \\
\hline 27 & p.(W157R) & HTTM (TMD3) & $\begin{array}{l}\text { c.2085-5T>C } \\
\text { (splice) }\end{array}$ & Gla domain & $\mathrm{x}$ & $\mathrm{x}$ & $\mathrm{x}$ & \\
\hline 28 & p.(S284P) & HTTM & p.(W315X) & HTTM & $\mathrm{x}$ & & & \\
\hline 29 & p.(G125R) & HTTM (TMD2) & p.(D534V) & $\begin{array}{c}\text { near } \\
\text { PP-BS+RmlC-like }\end{array}$ & $\mathrm{x}$ & & $\mathrm{x}$ & \\
\hline 47 & p.(D15_F71del) & $\begin{array}{l}\text { N-terminus + } \\
\text { HTTM (TMD1) }\end{array}$ & p.(D15_F71)del & $\begin{array}{c}\text { N-terminus + } \\
\text { HTTM (TMD1) }\end{array}$ & & & & $\S$ \\
\hline
\end{tabular}

CP: chondrodysplasia punctata; FD: facial dysmorphia; Gla: gamma-carboxyglutamate; HTTM: horizontally transferred transmembrane domain; Id: identification number; PP-BS: propeptide binding site; RBM: reduced bone mass; RmlC: deoxythymidine-6-deoxy-D-xylo-4-hexulose 3,5 epimerase (EC5.1.3.13); RmlC-like: RmlC-like jelly roll fold; splice: splice site mutation; RmlC-like: RmlC-like jelly roll fold; TMD: transmembrane domain; * stunted growth, ${ }^{\dagger}$ skeletal abnormalities, ${ }^{\ddagger}$ telebrachydactyly, ${ }^{\circledR}$ clinodactyly, nephrocalcinosis and calcification of the trachea and bronchi.

\subsubsection{VKCFD1}

Thirty-three patients had VKCFD1 (Table 8), 25 of which had a deficiency of all VK-dependent coagulation factors (P1-P7, P9, P12-P16, P19-P22, P25, P26, P28-P30, P44, and P47). Defective FX activity was present in all patients, FII impairment in 30 patients, FVII deficiency in 31 patients and FIX was abnormally low in 24 patients. Of note, FIX deficiency was only present in those patients in whom all coagulation factors were deficient. Of the 33 patients with VKCFD1, 21 had symptoms of increased bleeding tendency, including intra-articular bleeding (e.g., knee hemarthrosis), abnormal bleeding after injuries, vaccination or surgery (e.g., after dental extraction) and spontaneous bleeding (e.g., vaginal, cerebral, and gingival). Ten patients were severely affected with symptoms before the age of one year (P1, P2, P7, P15, P16, P23, P26, P30, P44, and P46): all but P23 had a combined deficiency of FII, FVII, FIX and FX; for P46 the FIX function was not determined; and none of the severely affected patients had cutis laxa or other PXE-like skin or eye manifestations. Eleven patients developed a bleeding phenotype at an older age (P5, P6, P10-P12, P17, P19, P24, P25, P29, and P47), four of which had skin symptoms (P10, P11, P17, and P19) and three eye manifestations (P10, P11, and P17) at the time of publication. 
Table 8. VKCFD1 in patients with GGCX mutations. This table gives an overview of all patients in the analyzed cohort with VKCFD1. For each patient, the GGCX mutations on both alleles and the affected protein domain are stated (protein annotation). Further, an overview of the coagulation factor function (percent of normal activity or in $\mathrm{U} / \mathrm{dL}$ or $\mathrm{U} / \mathrm{mL}$ ), aPTT and PT is given, it is stated if patients were symptomatic within the first year of life. Reference values are stated between brackets if they were mentioned in the original article.

\begin{tabular}{|c|c|c|c|c|c|c|c|c|c|c|c|c|}
\hline \multirow[b]{2}{*}{ Id } & \multicolumn{2}{|c|}{ Allele 1} & \multicolumn{2}{|c|}{ Allele 2} & \multirow[b]{2}{*}{ PT } & \multirow[b]{2}{*}{ INR } & \multirow[b]{2}{*}{ aPTT } & \multirow[b]{2}{*}{ FII } & \multirow[b]{2}{*}{ FVII } & \multirow[b]{2}{*}{ FIX } & \multirow[b]{2}{*}{ FX } & \multirow{2}{*}{$\begin{array}{l}\text { Symptoms in } \\
\text { 1st Year of Life }\end{array}$} \\
\hline & Annotation & $\begin{array}{l}\text { Protein } \\
\text { Domain }\end{array}$ & Annotation & $\begin{array}{l}\text { Protein } \\
\text { Domain }\end{array}$ & & & & & & & & \\
\hline 1 & p.(L394R) & Glu-BS & p.(L394R) & Glu-BS & $>120 \mathrm{~s}$ & - & $>180 \mathrm{~s}$ & $\begin{array}{c}2 \mathrm{U} / \mathrm{dL} \\
{[77-125 \mathrm{U} / \mathrm{dL}]}\end{array}$ & $\begin{array}{c}3 \mathrm{U} / \mathrm{dL} \\
{[63-139 \mathrm{U} / \mathrm{dL}]}\end{array}$ & $\begin{array}{c}8 \mathrm{U} / \mathrm{dL} \\
{[63-155 \mathrm{U} / \mathrm{dL}]}\end{array}$ & $\begin{array}{c}2 \mathrm{U} / \mathrm{dL} \\
{[55-160 \mathrm{U} / \mathrm{dL}]}\end{array}$ & yes \\
\hline 2 & p.(L394R) & Glu-BS & p.(L394R) & Glu-BS & - & - & - & $\begin{array}{c}24 \mathrm{U} / \mathrm{dL} \\
{[77-125 \mathrm{U} / \mathrm{dL}]}\end{array}$ & $\begin{array}{c}23 \mathrm{U} / \mathrm{dL} \\
{[63-139 \mathrm{U} / \mathrm{dL}]}\end{array}$ & $\begin{array}{c}8 \mathrm{U} / \mathrm{dL} \\
{[63-155 \mathrm{U} / \mathrm{dL}]}\end{array}$ & $\begin{array}{c}20 \mathrm{U} / \mathrm{dL} \\
{[55-160 \mathrm{U} / \mathrm{dL}]}\end{array}$ & yes \\
\hline 3 & p.(L394R) & Glu-BS & p.(L394R) & Glu-BS & nd* & nd $*$ & nd $*$ & nd* & nd* & nd* & nd* & no \\
\hline 4 & p.(L394R) & Glu-BS & p.(L394R) & Glu-BS & nd $^{*}$ & nd $^{*}$ & nd $^{*}$ & nd $^{*}$ & nd $^{*}$ & nd $^{*}$ & nd $^{*}$ & no \\
\hline 5 & p.(W157R) & HTTM (TMD3) & p.(T591K) & RmlC-like & $\begin{array}{c}49.5 \mathrm{~s} \\
{[11.5 \mathrm{~s}]}\end{array}$ & - & $60 \mathrm{~s}[30 \mathrm{~s}]$ & $9 \% *$ & $6 \% *$ & $7 \% *$ & $5 \% *$ & no \\
\hline 6 & p.(W157R) & HTTM (TMD3) & p.(T591K) & RmlC-like & $\begin{array}{l}>60 \mathrm{~s} \\
{[11.5 \mathrm{~s}]}\end{array}$ & - & $56 \mathrm{~s}[30 \mathrm{~s}]$ & $14 \% *$ & $7 \% *$ & $\mathrm{nd}^{*}$ & $7 \% *$ & no \\
\hline 7 & p.(D153G) & HTTM (TMD3) & p.(M174R) & HTTM & $\begin{array}{c}11 \% \\
{[70 \%-100 \%]}\end{array}$ & - & $\begin{array}{c}\text { ratio } 1.65 \\
{[0.84-1.21]}\end{array}$ & $\begin{array}{c}26 \% \\
{[50 \%-150 \%]}\end{array}$ & $\begin{array}{c}<1 \% \\
{[50 \%-150 \%]}\end{array}$ & $\begin{array}{c}12 \% \\
{[50 \%-150 \%]}\end{array}$ & $\begin{array}{c}13 \% \\
{[50 \%-150 \%]}\end{array}$ & yes \\
\hline 8 & p.(V255M) & HTTM & p.(S300F) & HTTM (TMD4) & $\begin{array}{c}18.1 \mathrm{~s} \\
{[12-15 \mathrm{~s}]}\end{array}$ & $\begin{array}{c}1.2 \\
{[0.8-1.2]} \\
\end{array}$ & $\begin{array}{c}\text { PTT: } 43.3 \mathrm{~s} \\
\text { [25-41 s] }\end{array}$ & $\begin{array}{c}64 \% \\
{[60 \%-150 \%]}\end{array}$ & $\begin{array}{c}108 \% \\
{[60 \%-160 \%]}\end{array}$ & $\begin{array}{c}62 \% \\
{[60 \%-160 \%]}\end{array}$ & $\begin{array}{c}33 \% \\
{[60 \%-160 \%]}\end{array}$ & no \\
\hline 9 & p.(V255M) & HTTM & p.(S300F) & HTTM (TMD4) & $\begin{array}{c}21.6 \mathrm{~s} \\
{[12-15 \mathrm{~s}]}\end{array}$ & $\begin{array}{c}1.9 \\
{[0.8-1.2]}\end{array}$ & $\begin{array}{c}32.1 \mathrm{~s} \\
{[25-41 \mathrm{~s}]}\end{array}$ & $\begin{array}{c}33 \% \\
{[60 \%-150 \%]}\end{array}$ & $\begin{array}{c}31 \% \\
{[60 \%-160 \%]}\end{array}$ & $\begin{array}{c}56 \% \\
{[60 \%-160 \%]}\end{array}$ & $\begin{array}{c}18 \% \\
{[60 \%-160 \%]}\end{array}$ & no \\
\hline 10 & p.(R83W) & HTTM & p.(Q374X) & TMD5 & $\begin{array}{c}21-31 \mathrm{~s} \\
{[11-14 \mathrm{~s}]}\end{array}$ & - & - & $\begin{array}{c}20 \% \\
{[65 \%-150 \%]}\end{array}$ & $\begin{array}{c}74-117 \% \\
{[55 \%-185 \%]}\end{array}$ & $\begin{array}{c}48-71 \% \\
{[50 \%-180 \%]}\end{array}$ & $\begin{array}{c}20-22 \% \\
{[65 \%-185 \%]}\end{array}$ & no \\
\hline 11 & p.(R83W) & HTTM & p.(Q374X) & TMD5 & $\begin{array}{c}21-31 \mathrm{~s} \\
{[11-14 \mathrm{~s}]}\end{array}$ & - & - & $\begin{array}{c}18 \% \\
{[65 \%-150 \%]}\end{array}$ & $\begin{array}{c}88 \% \\
{[55 \%-185 \%]}\end{array}$ & $\begin{array}{c}56 \% \\
{[50 \%-180 \%]}\end{array}$ & $\begin{array}{c}18 \% \\
{[65 \%-185 \%]}\end{array}$ & no \\
\hline 12 & p.(M174R) & HTTM & p.(I532T) & RmlC-like & - & $\begin{array}{c}2.76 \\
{[0.9-1.14]}\end{array}$ & $\begin{array}{c}\text { ratio } 1.44 \\
{[0.83-1.18]}\end{array}$ & $\begin{array}{c}20 \% \\
{[70 \%-131 \%]}\end{array}$ & $\begin{array}{c}34 \% \\
{[69 \%-134 \%]}\end{array}$ & $\begin{array}{c}42 \% \\
{[71 \%-139 \%]}\end{array}$ & $\begin{array}{c}20 \% \\
{[70 \%-13 \%]}\end{array}$ & no \\
\hline 13 & p.(G72_L124del) & $\begin{array}{c}\text { HTTM } \\
\text { (TMD1 and -2) }\end{array}$ & p.(R485P) & near PP-BS & - & - & - & $21 \% *$ & $42 \% *$ & nd * & $36 \% *$ & no \\
\hline 14 & p.(W501S) & PP-BS & p.(W501S) & PP-BS & $>100 \mathrm{~s}$ & - & PTT: >100 s & $\mathrm{nd}^{*}$ & $<1 \% *$ & $9 \% *$ & $26 \% *$ & yes \\
\hline 15 & c. $214+1 \mathrm{G}>\mathrm{T}$ (splice) & HTTM (TMD1) & $\begin{array}{c}\text { c.1609+3A>G } \\
\text { (splice) }\end{array}$ & $\begin{array}{c}\text { near PP-BS + } \\
\text { RmlC-like }\end{array}$ & $\begin{array}{c}69.8 \mathrm{~s} \\
{[8.4-12.0 \mathrm{~s}]}\end{array}$ & 7 & $\begin{array}{c}45 \mathrm{~s} \\
{[21-33 \mathrm{~s}]}\end{array}$ & $\begin{array}{c}2 \% \\
{[70 \%-130 \%]}\end{array}$ & $\begin{array}{c}3 \% \\
{[65 \%-140 \%]}\end{array}$ & $\begin{array}{c}4 \% \\
{[65 \%-140 \%]}\end{array}$ & $\begin{array}{c}<3 \% \\
{[60 \%-130 \%]}\end{array}$ & yes \\
\hline 16 & p.(W493S) & near PP-BS & p.(W493S) & near PP-BS & - & $\begin{array}{c}1.81 \\
{[0.8-1.2]}\end{array}$ & - & $\begin{array}{c}66 \% \\
{[90 \%-150 \%]}\end{array}$ & $\begin{array}{c}26 \% \\
{[90 \%-150 \%]}\end{array}$ & $\begin{array}{c}70 \% \\
{[90 \%-150 \%]}\end{array}$ & $15[90 \%-150 \%]$ & no \\
\hline 17 & p.(R476C) & near PP-BS & - & - & - & $\begin{array}{c}1.97 \\
{[0.8-1.2]} \\
\end{array}$ & - & $\begin{array}{c}38 \% \\
{[90 \%-150 \%]}\end{array}$ & $\begin{array}{c}50 \% \\
{[90 \%-150 \%]}\end{array}$ & $\begin{array}{c}103 \% \\
{[90 \%-150 \%]}\end{array}$ & $\begin{array}{c}20 \% \\
{[90 \%-150 \%]}\end{array}$ & no \\
\hline 18 & p.(R476H) & near PP-BS & - & - & - & $\begin{array}{c}2.19 \\
{[0.8-1.2]}\end{array}$ & - & $\begin{array}{c}38 \% \\
{[90 \%-150 \%]}\end{array}$ & $\begin{array}{c}62 \% \\
{[90 \%-150 \%]}\end{array}$ & $\begin{array}{c}90 \% \\
{[90 \%-150 \%]}\end{array}$ & $\begin{array}{c}17 \% \\
{[90 \%-150 \%]}\end{array}$ & no \\
\hline
\end{tabular}


Table 8. Cont

\begin{tabular}{|c|c|c|c|c|c|c|c|c|c|c|c|c|}
\hline \multirow[b]{2}{*}{ Id } & \multicolumn{2}{|c|}{ Allele 1} & \multicolumn{2}{|c|}{ Allele 2} & \multirow[b]{2}{*}{ PT } & \multirow[b]{2}{*}{ INR } & \multirow[b]{2}{*}{ aPTT } & \multirow[b]{2}{*}{ FII } & \multirow[b]{2}{*}{ FVII } & \multirow[b]{2}{*}{ FIX } & \multirow[b]{2}{*}{ FX } & \multirow{2}{*}{$\begin{array}{l}\text { Symptoms in } \\
\text { 1st Year of Life }\end{array}$} \\
\hline & Annotation & $\begin{array}{l}\text { Protein } \\
\text { Domain }\end{array}$ & Annotation & $\begin{array}{l}\text { Protein } \\
\text { Domain }\end{array}$ & & & & & & & & \\
\hline 19 & p.(Q374X) & TMD5 & p.(G537A) & RmlC-like & - & $1.7[0.8-1.2]$ & - & $\begin{array}{c}20 \% \\
{[90 \%-150 \%]}\end{array}$ & $\begin{array}{c}74 \% \\
{[90 \%-150 \%]}\end{array}$ & $\begin{array}{c}48 \% \\
{[90 \%-150 \%]}\end{array}$ & $\begin{array}{c}20 \% \\
{[90 \%-150 \%]}\end{array}$ & no \\
\hline 20 & p.(Q374X) & TMD5 & p.(G537A) & RmlC-like & - & $1.9[0.8-1.2]$ & - & $\begin{array}{c}18 \% \\
{[90 \%-150 \%]}\end{array}$ & $\begin{array}{c}88 \% \\
{[90 \%-150 \%]}\end{array}$ & $\begin{array}{c}56 \% \\
{[90 \%-150 \%]}\end{array}$ & $\begin{array}{c}18 \% \\
{[90 \%-150 \%]}\end{array}$ & no \\
\hline 21 & p.(H404P) & Glu-BS & p.(R485P) & near PP-BS & - & - & - & $35 \% *$ & $37 \% *$ & $54 \% *$ & $13 \%^{*}$ & no \\
\hline 22 & p.(W315X) & HTTM & p.(R485P) & near PP-BS & - & - & - & $30 \% *$ & $37 \% *$ & $53 \% *$ & $29 \% *$ & no \\
\hline 23 & p.(R204C) & HTTM & $\mathrm{p} .(\mathrm{R} 204 \mathrm{C})$ & HTTM & - & - & - & - & $\begin{array}{c}15 \%(\text { after VK } \\
\text { R/)* }\end{array}$ & - & $6 \% *$ & yes \\
\hline 24 & p.(R204C) & HTTM & p.(R204C) & HTTM & - & - & - & - & $31 \% *$ & - & $20 \% *$ & no \\
\hline 25 & p.(R83P) & HTTM & p.(R83P) & HTTM & - & $1.7^{*}$ & - & $27 \% *$ & $77 \% *$ & $56 \% *$ & $33 \% *$ & no \\
\hline 26 & p.(R204C) & HTTM & p.(R204C) & HTTM & - & - & - & - & - & nd* & nd* & yes \\
\hline 27 & p.(W157R) & HTTM (TMD3) & $\begin{array}{c}\text { c.2085-5T>C } \\
\text { (splice) }\end{array}$ & $\begin{array}{l}\text { near Gla } \\
\text { domain }\end{array}$ & - & - & - & - & $54 \% *$ & - & $28 \% *$ & no \\
\hline 28 & p.(S284P) & HTTM & p.(W315X) & HTTM & - & - & - & $41 \% *$ & $27 \% *$ & nd* & $18 \% *$ & no \\
\hline 29 & p.(G125R) & HTTM (TMD2) & p.(D534V) & $\begin{array}{c}\text { near PP-BS + } \\
\text { RmlC-like }\end{array}$ & - & - & - & $30 \% *$ & $49 \% *$ & nd * & $28 \% *$ & no \\
\hline 30 & p.(W501S) & PP-BS & p.(W501S) & PP-BS & & . & & $95 \% *$ & $35 \%{ }^{*}$ & nd $^{*}$ & $30 \% *$ & yes \\
\hline 31 & p.(F74_G125del) & $\begin{array}{l}\text { HTTM (TMD1 } \\
\text { and -2) }\end{array}$ & p.(F74_G125del) & $\begin{array}{c}\text { HTTM } \\
\text { (TMD1 and -2) }\end{array}$ & - & - & - & - & - & - & - & no VKCFD1 \\
\hline 32 & p.(F74_G125del) & $\begin{array}{c}\text { HTTM } \\
\text { (TMD1 and -2) }\end{array}$ & p.(F74_G125del) & $\begin{array}{c}\text { HTTM } \\
\text { (TMD1 and -2) }\end{array}$ & $\begin{array}{c}100 \% \\
{[80 \%-100 \%]}\end{array}$ & - & $\begin{array}{c}\text { PTT: } 33.2 \mathrm{~s} \\
{[25-45 \mathrm{~s}]}\end{array}$ & $\begin{array}{c}76.2 \% \\
{[70 \%-80 \%]}\end{array}$ & $\begin{array}{l}86.5 \% \\
{[>60 \%]}\end{array}$ & $\begin{array}{c}70.5 \% \\
{[64 \%-84 \%]}\end{array}$ & $\begin{array}{c}67.1 \% \\
{[53 \%-122 \%]}\end{array}$ & no VKCFD1 \\
\hline 33 & p.(F74_G125del) & $\begin{array}{c}\text { HTTM } \\
\text { (TMD1 and -2) }\end{array}$ & p.(F74_G125del) & $\begin{array}{c}\text { HTTM } \\
\text { (TMD1 and -2) }\end{array}$ & $\begin{array}{c}100 \% \\
{[80 \%-100 \%]}\end{array}$ & - & $\begin{array}{c}\text { PTT: } 36.2 \mathrm{~s} \\
{[25-45 \mathrm{~s}]}\end{array}$ & $\begin{array}{c}73.2 \% \\
{[70 \%-80 \%]}\end{array}$ & $\begin{array}{c}94.8 \% \\
{[>60 \%]}\end{array}$ & $\begin{array}{c}68.7 \% \\
{[64 \%-84 \%]}\end{array}$ & $\begin{array}{c}72.4 \% \\
{[53 \%-122 \%]}\end{array}$ & no VKCFD1 \\
\hline 34 & p.(F74_G125del) & $\begin{array}{c}\text { HTTM } \\
\text { (TMD1 and -2) }\end{array}$ & p.(F74_G125del) & $\begin{array}{c}\text { HTTM } \\
\text { (TMD1 and -2) }\end{array}$ & $\begin{array}{c}100 \% \\
{[80 \%-100 \%]}\end{array}$ & - & $\begin{array}{c}\text { PTT: } 38.5 \mathrm{~s} \\
{[25-45 \mathrm{~s}]}\end{array}$ & $\begin{array}{c}78.8 \% \\
{[70 \%-80 \%]}\end{array}$ & $\begin{array}{l}119.3 \% \\
{[>60 \%]}\end{array}$ & $\begin{array}{c}69.8 \% \\
{[64 \%-84 \%]}\end{array}$ & $\begin{array}{c}58.3 \% \\
{[53 \%-122 \%]}\end{array}$ & no VKCFD1 \\
\hline 35 & p.(F74_G125del) & $\begin{array}{c}\text { HTTM } \\
\text { (TMD1 and -2) }\end{array}$ & p.(F74_G125del) & $\begin{array}{c}\text { HTTM } \\
\text { (TMD1 and -2) }\end{array}$ & $\begin{array}{c}100 \% \\
{[80 \%-100 \%]}\end{array}$ & - & $\begin{array}{c}\text { PTT: } 32.6 \mathrm{~s} \\
{[25-45 \mathrm{~s}]}\end{array}$ & $\begin{array}{c}74.1 \% \\
{[70 \%-80 \%]}\end{array}$ & $\begin{array}{l}126.7 \% \\
{[>60 \%]}\end{array}$ & $\begin{array}{c}69 \% \\
{[64 \%-84 \%]}\end{array}$ & $\begin{array}{c}66.8 \% \\
{[53 \%-122 \%]}\end{array}$ & no VKCFD1 \\
\hline 36 & p.(F74_G125del) & $\begin{array}{c}\text { HTTM } \\
\text { (TMD1 and -2) }\end{array}$ & p.(F74_G125del) & $\begin{array}{c}\text { HTTM } \\
\text { (TMD1 and -2) }\end{array}$ & $\begin{array}{c}94.7 \% \\
{[80 \%-100 \%]}\end{array}$ & - & $\begin{array}{l}\text { PTT: } 43.1 \mathrm{~s} \\
{[25-45 \mathrm{~s}]}\end{array}$ & $\begin{array}{c}73.1 \% \\
{[70 \%-80 \%]}\end{array}$ & $\begin{array}{l}76.3 \% \\
{[>60 \%]}\end{array}$ & $\begin{array}{c}70.4 \% \\
{[64 \%-84 \%]}\end{array}$ & $\begin{array}{c}71.2 \% \\
{[53 \%-122 \%]}\end{array}$ & no VKCFD1 \\
\hline 37 & p.(F74_G125del) & $\begin{array}{c}\text { HTTM } \\
\text { (TMD1 and -2) }\end{array}$ & p.(F74_G125del) & $\begin{array}{c}\text { HTTM } \\
\text { (TMD1 and -2) }\end{array}$ & $\begin{array}{c}100 \% \\
{[80 \%-100 \%]}\end{array}$ & - & $\begin{array}{c}\text { PTT: } 31.5 \mathrm{~s} \\
{[25-45 \mathrm{~s}]}\end{array}$ & $83 \%[70 \%-80 \%]$ & $\begin{array}{c}79 \% \\
{[>60 \%]}\end{array}$ & $\begin{array}{c}76.9 \% \\
{[64 \%-84 \%]}\end{array}$ & $\begin{array}{c}58 \% \\
{[53 \%-122 \%]}\end{array}$ & no VKCFD1 \\
\hline 38 & p.(F74_G125del) & $\begin{array}{c}\text { HTTM } \\
\text { (TMD1 and -2) }\end{array}$ & p.(F74_G125del) & $\begin{array}{c}\text { HTTM } \\
\text { (TMD1 and -2) }\end{array}$ & - & - & - & - & - & - & - & no VKCFD1 \\
\hline 39 & p.(F74_G125del) & $\begin{array}{c}\text { HTTM } \\
\text { (TMD1 and -2) }\end{array}$ & p.(F74_G125del) & $\begin{array}{c}\text { HTTM } \\
\text { (TMD1 and -2) }\end{array}$ & $\begin{array}{c}100 \% \\
{[80 \%-100 \%]}\end{array}$ & - & $\begin{array}{c}\text { PTT: } 37.8 \mathrm{~s} \\
{[25-45 \mathrm{~s}]}\end{array}$ & $\begin{array}{c}77.8 \% \\
{[70 \%-80 \%]}\end{array}$ & $\begin{array}{c}73.7 \% \\
{[>60 \%]}\end{array}$ & - & $\begin{array}{c}55.9 \% \\
{[53 \%-122 \%]}\end{array}$ & no VKCFD1 \\
\hline 40 & p.(F74_G125del) & $\begin{array}{c}\text { HTTM } \\
\text { (TMD1 and -2) }\end{array}$ & p.(F74_G125del) & $\begin{array}{c}\text { HTTM } \\
\text { (TMD1 and -2) }\end{array}$ & - & - & - & - & - & - & - & no VKCFD1 \\
\hline
\end{tabular}


Table 8. Cont.

\begin{tabular}{|c|c|c|c|c|c|c|c|c|c|c|c|c|}
\hline \multirow[b]{2}{*}{ Id } & \multicolumn{2}{|c|}{ Allele 1} & \multicolumn{2}{|c|}{ Allele 2} & \multirow[b]{2}{*}{ PT } & \multirow[b]{2}{*}{ INR } & \multirow[b]{2}{*}{ aPTT } & \multirow[b]{2}{*}{ FII } & \multirow[b]{2}{*}{ FVII } & \multirow[b]{2}{*}{ FIX } & \multirow[b]{2}{*}{ FX } & \multirow{2}{*}{$\begin{array}{l}\text { Symptoms in } \\
\text { 1st Year of Life }\end{array}$} \\
\hline & Annotation & $\begin{array}{l}\text { Protein } \\
\text { Domain }\end{array}$ & Annotation & $\begin{array}{l}\text { Protein } \\
\text { Domain }\end{array}$ & & & & & & & & \\
\hline 41 & p.(F74_G125del) & $\begin{array}{c}\text { HTTM } \\
\text { (TMD1 and -2) }\end{array}$ & p.(F74_G125del) & $\begin{array}{c}\text { HTTM } \\
\text { (TMD1 and -2) }\end{array}$ & $\begin{array}{c}96.4 \% \\
{[80 \%-100 \%]}\end{array}$ & - & $\begin{array}{c}\text { PTT: } 38.9 \mathrm{~s} \\
{[25-45 \mathrm{~s}]}\end{array}$ & $\begin{array}{c}78.1 \% \\
{[70 \%-80 \%]}\end{array}$ & $\begin{array}{c}81.9 \% \\
{[>60 \%]}\end{array}$ & $\begin{array}{c}70 \% \\
{[64 \%-84 \%]}\end{array}$ & $\begin{array}{c}67.7 \% \\
{[53 \%-122 \%]}\end{array}$ & no VKCFD1 \\
\hline 42 & p.(F74_G125del) & $\begin{array}{c}\text { HTTM } \\
\text { (TMD1 and -2) }\end{array}$ & p.(F74_G125del) & $\begin{array}{c}\text { HTTM } \\
\text { (TMD1 and -2) }\end{array}$ & $\begin{array}{c}100 \% \\
{[80 \%-100 \%]} \\
\end{array}$ & - & $\begin{array}{c}\text { PTT: } 38.9 \mathrm{~s} \\
\text { [25-45 s] }\end{array}$ & $\begin{array}{c}74.2 \% \\
{[70 \%-80 \%]} \\
\end{array}$ & $\begin{array}{l}129.3 \% \\
{[>60 \%]} \\
\end{array}$ & $\begin{array}{c}68.5 \% \\
{[64 \%-84 \%]} \\
\end{array}$ & $\begin{array}{c}72.8 \% \\
{[53 \%-122 \%]} \\
\end{array}$ & no VKCFD1 \\
\hline 43 & p.(F74_G125del) & $\begin{array}{c}\text { HTTM } \\
\text { (TMD1 and -2) }\end{array}$ & p.(F74_G125del) & $\begin{array}{c}\text { HTTM } \\
\text { (TMD1 and -2) }\end{array}$ & $\begin{array}{c}100 \% \\
{[80 \%-100 \%]}\end{array}$ & - & $\begin{array}{l}\text { PTT: } 31.8 \mathrm{~s} \\
{[25-45 \mathrm{~s}]}\end{array}$ & $\begin{array}{c}76 \% \\
{[70 \%-80 \%]}\end{array}$ & $\begin{array}{c}106 \% \\
{[>60 \%]}\end{array}$ & $\begin{array}{c}68.6 \% \\
{[64 \%-84 \%]}\end{array}$ & $\begin{array}{c}71.5 \% \\
{[53-122 \%]}\end{array}$ & no VKCFD1 \\
\hline 44 & /(14 bp del I1) & - & /(14 bp del I1) & - & $>100 \mathrm{~s}$ & - & $>150 \mathrm{~s}$ & $0.35 \mathrm{U} / \mathrm{mL}^{*}$ & $0.08 \mathrm{U} / \mathrm{mL}^{*}$ & $\mathrm{nd}^{+}$ & $0.21 \mathrm{U} / \mathrm{mL}^{*}$ & yes \\
\hline 45 & /(14 bp del I1) & - & /(14 bp del I1) & - & $30 \mathrm{~s}$ & - & $38 \mathrm{~s}$ & $0.09 \mathrm{U} / \mathrm{mL}^{*}$ & $0.21 \mathrm{U} / \mathrm{mL}^{*}$ & $0.59 \mathrm{U} / \mathrm{mL}$ & $0.17 \mathrm{U} / \mathrm{mL}^{*}$ & no \\
\hline 46 & p.(W493C) & near PP-BS & p.(R704X) & $\begin{array}{c}\text { near } \\
\text { Gla-domin }\end{array}$ & $\begin{array}{l}>100 \mathrm{~s} \\
{[12.8 \mathrm{~s}]}\end{array}$ & - & - & $3 \% *$ & $2 \% *$ & - & $3 \% *$ & yes \\
\hline 47 & p.(D15_F71del) & $\begin{array}{c}\text { N-terminus + } \\
\text { HTTM (TMD1) }\end{array}$ & p.(D15_F71del) & $\begin{array}{c}\text { N-terminus + } \\
\text { HTTM (TMD1) }\end{array}$ & $98.9 \mathrm{~s}$ & 9 & $53.1 \mathrm{~s}$ & $2 \% *$ & $1.7 \% *$ & $4.7 \% *$ & $2 \% *$ & no \\
\hline
\end{tabular}

14 bp del I1: 14 base pair deletion intron 1; aPTT: activated partial thromboplastin time; FII: coagulation factor II; FVII: coagulation factor VII; FIX: coagulation factor IX; FX: coagulation factor X; Glu-BS: glutamate binding site; HTTM: horizontally transferred transmembrane domain; Id: identification number; INR: international normalized ratio; nd: not described; PT:

prothrombin time; PP-BS: propeptide binding site; RmlC: deoxythymidine-6-deoxy-D-xylo-4-hexulose 3,5 epimerase (EC5.1.3.13); RmlC-like: RmlC-like jelly roll fold; splice: splice site mutation; TMD: transmembrane domain; VK R/: vitamin K therapy; ${ }^{*}$ no reference values in original article or no values, but clearly stated in full-text as deficient. ${ }^{+}$deficient factor IX confirmed at 9 years of age. 
Twenty-five VKCFD1 patients received a treatment with VK, the details of which are summarized in Table 9. Regarding the hematological parameters, 17 patients responded well to the treatment (P1, P2, P7, P10, P12 (only international normalized ratio (INR) and aPTT), P13, P15, P21, P22, P23, P24, P27, P28, P29, P44, P45, and P46), five patients showed no or only a limited response (P5, $\mathrm{P} 12$ (coagulation factors), P25, P30, and P47) and for three patients the initial VK deficiency was mentioned in the manuscript without details on the individual clotting parameters so an evaluation of the effect of the VK treatment was not possible (P3, P4, and P26). Non-hemostatic parameters were determined before treatment and after initiation of the VK therapy in six patients: in five patients the ratio uncarboxylated(uc) OC/gamma-carboxylated(c) OC decreased significantly but remained supranormal (P21, P27, P28, P29, and P47), in one patient the desphospho-uncarboxylated MGP serum level was measured with no response to treatment (P7). Nine patients had no new bleeding episodes after initiation of the VK treatment (P2, P3, P4, P7, P10, P12, P15, P30, and P46), two patients had recurrent bleeding on VK treatment (P1, and P47) and for six patients the clinical outcome was not mentioned (P5, P14, P21, P23, P24, and P44). In three patients, VKCFD1 was an asymptomatic incidental finding with either no new bleeding after start of VK supplementation (P13, and P22) or no mentioning of the clinical effect of the treatment (P45). In six patients the clinical effect of the VK treatment was mentioned. For five of these patients, a good response to VK supplementation was mentioned without details on the clinical outcome (P25, P26, P27, P28, and P29).

Twenty-one distinct genotypes were associated with VKCFD1, encompassing 33 individual mutations. Fourteen mutations were located in the HTTM domain (one in TMD1, one in TMD2, two in TMD1 and -2, two in TMD3, and one in TMD4), one mutation affected the N-terminal region and the first part of the HTTM domain (TMD1), seven mutations were located in or near the propeptide binding site, two in the glutamate binding site, three in the RmlC-like jelly roll fold, one in the RmlC-like jelly roll fold/near the propeptide binding site, two near the C-terminal Gla-domain, one in TMD5, and one mutation was located in intron 1 of the GGCX gene. In the whole cohort of patients with VKCFD1, 14/33 harbored homozygous mutations, whereas in the severely affected cohort 6/9 genotypes were homozygous. Moreover, in the severe cohort, both mutations were located in or near the same domain in all but two patients (P15, and P46). In P17 and P18 only one GGCX mutation could be identified. The genotype of $15 / 33$ patients contained no mutations in the HTTM domain. The mutational spectrum between patients with a good or bad response to VK supplementation (clinical and hemostatic parameters) seems similar. With regards to the non-hemostatic parameters, four out of five patients with a decreasing ratio $\mathrm{ucOC} / \mathrm{cOC}$ harbor at least one mutation in the HTTM domain. There are no patients mentioned who did not have an alteration in this ratio so a potential difference in the mutational spectrum cannot be assessed. 
Table 9. Vitamin K treatment in VKCFD1 patients with GGCX mutations. This table gives an overview of all patients who received vitamin K treatment for their coagulation factor deficiency and the response to treatment. For each patient, an overview of the PT, aPTT, coagulation factor function (percent of normal activity or in $\mathrm{U} / \mathrm{dL}$ or $\mathrm{U} / \mathrm{mL}$ ) prior to therapy is given (in italics) and extrahepatic (non-hemostatic) before treatment parameters are shown (in italics), if determined. Further, the clinical response to treatment is mentioned. For P21, P27, P28, and P29, the response to treatment for the ucOC/cOC ratio is given, but the specific vitamin K dose at the time of blood sampling is not mentioned in the original article. Reference values are stated between brackets if they were mentioned in the original article.

\begin{tabular}{|c|c|c|c|c|c|c|c|c|c|c|c|c|}
\hline Id & VK R/(age) & PT & INR & aPTT & FII & FVII & FIX & FX & PC & ProS & $\begin{array}{l}\text { Extrahepatic } \\
\text { Proteins }\end{array}$ & $\begin{array}{c}\text { New } \\
\text { Bleeding } \\
\text { Episodes }\end{array}$ \\
\hline \multirow[t]{2}{*}{1} & before treatment & $>120 \mathrm{~s}$ & - & $>180 \mathrm{~s}$ & $\begin{array}{c}2 \mathrm{U} / \mathrm{dL} \\
{[77-125 \mathrm{U} / \mathrm{dL}]}\end{array}$ & $\begin{array}{c}3 U / d L \\
{[63-139 \mathrm{U} / \mathrm{dL}]}\end{array}$ & $\begin{array}{c}8 \mathrm{U} / \mathrm{dL} \\
{[63-155 \mathrm{U} / \mathrm{dL}]}\end{array}$ & $\begin{array}{c}2 \mathrm{U} / \mathrm{dL} \\
{[55-160 \mathrm{U} / \mathrm{dL}]}\end{array}$ & - & - & - & \\
\hline & $10 \mathrm{mg} \mathrm{sc} /$ week & - & - & - & $\begin{array}{c}18 \mathrm{U} / \mathrm{dL} \\
{[77-125 \mathrm{U} / \mathrm{dL}]}\end{array}$ & $\begin{array}{c}25 \mathrm{U} / \mathrm{dL} \\
{[63-139 \mathrm{U} / \mathrm{dL}]}\end{array}$ & $\begin{array}{c}37 \mathrm{U} / \mathrm{dL} \\
{[63-155 \mathrm{U} / \mathrm{dL}]}\end{array}$ & $\begin{array}{c}15 \mathrm{U} / \mathrm{dL} \\
{[55-160 \mathrm{U} / \mathrm{dL}]}\end{array}$ & $\begin{array}{c}45 \mathrm{U} / \mathrm{dL} \\
{[65-146 \mathrm{U} / \mathrm{dL}]}\end{array}$ & $\begin{array}{c}34 \mathrm{U} / \mathrm{dL} \\
{[74-126 \mathrm{U} / \mathrm{dL}]}\end{array}$ & - & yes \\
\hline \multirow[t]{2}{*}{2} & before treatment & - & - & - & $\begin{array}{c}24 \mathrm{U} / \mathrm{dL} \\
{[77-125 \mathrm{U} / \mathrm{dL}]}\end{array}$ & $\begin{array}{c}23 \mathrm{U} / \mathrm{dL} \\
{[63-139 \mathrm{U} / \mathrm{dL}]}\end{array}$ & $\begin{array}{c}8 \mathrm{UU} / \mathrm{dL} \\
{[63-155 \mathrm{U} / \mathrm{dL}]}\end{array}$ & $\begin{array}{c}20 \mathrm{U} / \mathrm{dL} \\
{[55-160 \mathrm{U} / \mathrm{dL}]}\end{array}$ & $\begin{array}{c}42 \mathrm{U} / \mathrm{dL} \\
{[65-146 \mathrm{U} / \mathrm{dL}]}\end{array}$ & $\begin{array}{c}35 \mathrm{U} / \mathrm{dL} \\
{[74-126 \mathrm{U} / \mathrm{dL}]}\end{array}$ & & \\
\hline & $10 \mathrm{mg} \mathrm{sc} /$ week & - & $2-3.5$ & - & $\begin{array}{c}45 \mathrm{U} / \mathrm{dL} \\
{[77-125 \mathrm{U} / \mathrm{dL}]}\end{array}$ & $\begin{array}{c}43 \mathrm{U} / \mathrm{dL} \\
{[63-139 \mathrm{U} / \mathrm{dL}]}\end{array}$ & $\begin{array}{c}89 \mathrm{U} / \mathrm{dL} \\
{[63-155 \mathrm{U} / \mathrm{dL}]}\end{array}$ & $\begin{array}{c}27 \mathrm{U} / \mathrm{dL} \\
{[55-160 \mathrm{U} / \mathrm{dL}]}\end{array}$ & $\begin{array}{c}73 \mathrm{U} / \mathrm{dL} \\
{[65-146 \mathrm{U} / \mathrm{dL}]}\end{array}$ & $\begin{array}{c}35 \mathrm{U} / \mathrm{dL} \\
{[74-126 \mathrm{U} / \mathrm{dL}]}\end{array}$ & - & no \\
\hline \multirow[t]{2}{*}{3} & before treatment & $n d^{*}$ & $n d^{*}$ & $n d^{*}$ & $n d^{*}$ & $n d^{*}$ & $n d^{*}$ & $n d^{*}$ & $n d^{*}$ & $n d^{*}$ & & \\
\hline & $10 \mathrm{mg} \mathrm{sc} /$ week & - & - & - & $\begin{array}{c}31 \mathrm{U} / \mathrm{dL} \\
{[77-125 \mathrm{U} / \mathrm{dL}]}\end{array}$ & $\begin{array}{c}23 \mathrm{U} / \mathrm{dL} \\
{[63-139 \mathrm{U} / \mathrm{dL}]}\end{array}$ & $\begin{array}{c}55 \mathrm{U} / \mathrm{dL} \\
{[63-155 \mathrm{U} / \mathrm{dL}]}\end{array}$ & $\begin{array}{c}17 \mathrm{U} / \mathrm{dL} \\
{[55-160 \mathrm{U} / \mathrm{dL}]}\end{array}$ & $\begin{array}{c}84 \mathrm{U} / \mathrm{dL} \\
{[65-146 \mathrm{U} / \mathrm{dL}]}\end{array}$ & $\begin{array}{c}28 \mathrm{U} / \mathrm{dL} \\
{[74-126 \mathrm{U} / \mathrm{dL}]}\end{array}$ & - & no \\
\hline \multirow[t]{2}{*}{4} & before treatment & $n d^{*}$ & $n d^{*}$ & $n d^{*}$ & $n d^{*}$ & $n d *$ & $n d *$ & $n d^{*}$ & $n d *$ & $n d^{*}$ & & \\
\hline & $10 \mathrm{mg} \mathrm{sc} /$ week & - & - & - & $\begin{array}{c}24 \mathrm{U} / \mathrm{dL} \\
{[77-125 \mathrm{U} / \mathrm{dL}]}\end{array}$ & $\begin{array}{c}47 \mathrm{U} / \mathrm{dL} \\
{[63-139 \mathrm{U} / \mathrm{dL}]}\end{array}$ & $\begin{array}{c}33 \mathrm{U} / \mathrm{dL} \\
{[63-155 \mathrm{U} / \mathrm{dL}]}\end{array}$ & $\begin{array}{c}16 \mathrm{U} / \mathrm{dL} \\
{[55-160 \mathrm{U} / \mathrm{dL}]}\end{array}$ & $\begin{array}{c}71 \mathrm{U} / \mathrm{dL} \\
{[65-146 \mathrm{U} / \mathrm{dL}]}\end{array}$ & $\begin{array}{c}57 \mathrm{U} / \mathrm{dL} \\
{[74-126 \mathrm{U} / \mathrm{dL}]}\end{array}$ & - & no \\
\hline \multirow[t]{2}{*}{5} & before treatment & $49.5 \mathrm{~s}[11.5 \mathrm{~s}]$ & - & $60 \mathrm{~s}[30 \mathrm{~s}]$ & $9 \% *$ & $6 \% *$ & $7 \% *$ & $5 \% *$ & - & - & & \\
\hline & $\begin{array}{c}10 \text { mg/d IM } 2 \text { weeks } \\
\text { (VK1) }\end{array}$ & no effect & - & no effect & - & - & - & - & - & - & - & ? \\
\hline \multirow[t]{3}{*}{7} & before treatment & $\begin{array}{c}11 \% \\
{[70-100 \%]}\end{array}$ & - & $\begin{array}{c}\text { ratio } 1.65 \\
{[0.84-1.21]}\end{array}$ & $\begin{array}{c}26 \% \\
{[50 \%-150 \%]}\end{array}$ & $\begin{array}{c}<1 \% \\
{[50 \%-150 \%]}\end{array}$ & $\begin{array}{c}12 \% \\
{[50 \%-150 \%]}\end{array}$ & $\begin{array}{c}13 \% \\
{[50 \%-150 \%]}\end{array}$ & $\begin{array}{c}7 \% \\
{[70 \%-140 \%]}\end{array}$ & $\begin{array}{c}10 \% \\
{[60 \%-120 \%]}\end{array}$ & $\begin{array}{c}d p-u c M G P: 2387 p M \\
{[35-546 p M]}\end{array}$ & \\
\hline & $\begin{array}{l}\text { a. } 10 \mathrm{mg} / \text { day po } 3 \\
\text { months (VK1) }\end{array}$ & $\begin{array}{c}36 \% \\
{[70-100 \%]} \\
\end{array}$ & - & $\begin{array}{l}\text { ratio: } 1.24 \\
{[0.84-1.21]} \\
\end{array}$ & $\begin{array}{c}46 \% \\
{[50 \%-150 \%]} \\
\end{array}$ & $\begin{array}{c}21 \% \\
{[50 \%-150 \%]} \\
\end{array}$ & $\begin{array}{c}53 \% \\
{[50 \%-150 \%]} \\
\end{array}$ & $\begin{array}{c}27 \% \\
{[50 \%-150 \%]} \\
\end{array}$ & $\begin{array}{c}13 \% \\
{[70 \%-140 \%]} \\
\end{array}$ & $\begin{array}{c}6 \% \\
{[60 \%-120 \%]} \\
\end{array}$ & $\begin{array}{l}\text { dp-ucMGP } 2750 \\
\text { pM [35-546 pM] }\end{array}$ & no \\
\hline & $\begin{array}{l}\text { b. } 20 \mathrm{mg} / \mathrm{d} \mathrm{po}>1 \mathrm{y}^{\dagger} \\
\text { (VK1) }\end{array}$ & $\begin{array}{c}42 \% \\
{[70-100 \%]}\end{array}$ & - & $\begin{array}{c}\text { ratio } 1.02 \\
{[0.84-1.21]}\end{array}$ & $\begin{array}{c}38 \% \\
{[50 \%-150 \%]}\end{array}$ & $\begin{array}{c}21 \% \\
{[50 \%-150 \%]}\end{array}$ & $\begin{array}{c}54 \% \\
{[50 \%-150 \%]}\end{array}$ & $\begin{array}{c}31 \% \\
{[50 \%-150 \%]}\end{array}$ & $\begin{array}{c}21 \% \\
{[70 \%-140 \%]}\end{array}$ & $\begin{array}{c}8 \% \\
{[60 \%-120 \%]}\end{array}$ & $\begin{array}{l}\text { dp-ucMGP } 2407 \\
\text { pM [35-546 pM] }\end{array}$ & no \\
\hline \multirow[t]{4}{*}{10} & before treatment & $\begin{array}{c}21-31 s \\
{[11-14 s]}\end{array}$ & - & - & $\begin{array}{c}20 \% \\
{[65 \%-150 \%]}\end{array}$ & $\begin{array}{c}74-117 \% \\
{[55 \%-185 \%]}\end{array}$ & $\begin{array}{c}48-71 \% \\
{[50 \%-180 \%]}\end{array}$ & $\begin{array}{c}20-22 \% \\
{[65 \%-185 \%]}\end{array}$ & - & - & - & \\
\hline & a. $1 \times$ parenteral (VK1) & - & normal & - & - & - & - & - & - & - & - & no \\
\hline & $\begin{array}{l}\text { b. } 10 \mathrm{mg} \mathrm{po} / \mathrm{d} 2 \text { weeks } \\
\text { (VK1) }\end{array}$ & - & - & - & normal & - & normal & normal & - & - & - & no \\
\hline & c. $5 \mathrm{mg} / \mathrm{d}(\mathrm{VK} 1)$ & $\begin{array}{c}14.9 \mathrm{~s} \\
{[12.3-14.6 \mathrm{~s}]}\end{array}$ & - & $\begin{array}{l}\text { PTT: } 25.9 \mathrm{~s} \\
{[27.3-35.3]}\end{array}$ & - & - & - & . & - & & 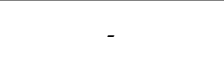 & no \\
\hline
\end{tabular}


Table 9. Cont

\begin{tabular}{|c|c|c|c|c|c|c|c|c|c|c|c|c|}
\hline Id & VK R/(age) & PT & INR & aPTT & FII & FVII & FIX & FX & PC & ProS & $\begin{array}{l}\text { Extrahepatic } \\
\text { Proteins }\end{array}$ & $\begin{array}{c}\text { New } \\
\text { Bleeding } \\
\text { Episodes }\end{array}$ \\
\hline \multirow[t]{3}{*}{12} & before treatment & - & $\begin{array}{c}2.76 \\
{[0.9-1.14]} \\
\end{array}$ & $\begin{array}{c}\text { ratio } 1.44 \\
{[0.83-1.18]} \\
\end{array}$ & $\begin{array}{c}20 \% \\
{[70 \%-131 \%]}\end{array}$ & $\begin{array}{c}34 \% \\
{[69 \%-134 \%]}\end{array}$ & $\begin{array}{c}42 \% \\
{[71 \%-139 \%]} \\
\end{array}$ & $\begin{array}{c}20 \% \\
{[70 \%-135 \%]}\end{array}$ & $\begin{array}{c}47 \% \\
{[65 \%-132 \%]} \\
\end{array}$ & - & - & \\
\hline & po & - & $\begin{array}{c}1.94 \\
{[0.9-1.14]}\end{array}$ & $\begin{array}{l}\text { ratio: } 1.26 \\
{[0.83-1.18]}\end{array}$ & $\begin{array}{c}24 \% \\
{[70 \%-131 \%]}\end{array}$ & $\begin{array}{c}34 \% \\
{[69 \%-134 \%]}\end{array}$ & $\begin{array}{c}54 \% \\
{[71 \%-139 \%]}\end{array}$ & $\begin{array}{c}18 \% \\
{[70 \%-135 \%]}\end{array}$ & $\begin{array}{c}47 \% \\
{[65 \%-132 \%]} \\
\end{array}$ & - & - & no \\
\hline & iv & - & $\begin{array}{c}1.98 \\
{[0.9-1.14]}\end{array}$ & $\begin{array}{c}\text { ratio: } 1.16 \\
\text { [0.83-1.18] }\end{array}$ & $\begin{array}{c}20 \% \\
{[70 \%-131 \%]}\end{array}$ & $\begin{array}{c}35 \% \\
{[69 \%-134 \%]}\end{array}$ & $\begin{array}{c}54 \% \\
{[71 \%-139 \%]}\end{array}$ & $\begin{array}{c}18 \% \\
{[70 \%-135 \%]}\end{array}$ & $\begin{array}{c}47 \% \\
{[65 \%-132 \%]}\end{array}$ & $\begin{array}{c}67 \% \\
{[62 \%-131 \%]}\end{array}$ & - & no \\
\hline \multirow[t]{2}{*}{13} & before treatment & - & - & - & $21 \% *$ & $42 \%$ * & $n d^{*}$ & $36 \% *$ & - & - & - & $\begin{array}{c}\text { Incidental } \\
\text { finding }\end{array}$ \\
\hline & $2 \mathrm{mg} / \mathrm{d} 6$ weeks & - & - & - & $40 \%$ & $62 \%$ & - & $65 \%$ & - & - & ucOC: $>9.4 \mu \mathrm{g} / \mathrm{L}^{*}$ & no \\
\hline \multirow[t]{2}{*}{14} & before treatment & $>100 \mathrm{~s}$ & - & PTT: $>100 \mathrm{~s}$ & $n d *$ & $<1 \% *$ & $9 \% *$ & $26 \% *$ & - & - & - & \\
\hline & $5 \mathrm{mg} / \mathrm{d}$ po (VK1) & - & - & - & - & - & - & - & - & - & - & ? \\
\hline \multirow[t]{3}{*}{15} & before treatment & $\begin{array}{c}69.8 \mathrm{~s} \\
{[8.4-12.0 \mathrm{~s}]} \\
\end{array}$ & 7 & $45 s[21-33 s]$ & $\begin{array}{c}2 \% \\
{[70 \%-130 \%]} \\
\end{array}$ & $\begin{array}{c}3 \% \\
{[65 \%-140 \%]} \\
\end{array}$ & $\begin{array}{c}4 \% \\
{[65 \%-140 \%]} \\
\end{array}$ & $\begin{array}{c}<3 \% \\
{[60 \%-130 \%]} \\
\end{array}$ & - & - & - & \\
\hline & a. $5 \mathrm{mg} / 2$ days po & $\begin{array}{c}16.1 \mathrm{~s} \\
{[8.4-12.0 \mathrm{~s}]}\end{array}$ & - & $29 \mathrm{~s}[21-33 \mathrm{~s}]$ & $\begin{array}{c}20 \% \\
{[70 \%-130 \%]}\end{array}$ & $\begin{array}{c}22 \% \\
{[65 \%-140 \%]}\end{array}$ & $\begin{array}{c}46 \% \\
{[65 \%-140 \%]}\end{array}$ & $\begin{array}{c}23 \% \\
{[60 \%-130 \%]}\end{array}$ & $\begin{array}{c}45 \% \\
{[70 \%-130 \%]}\end{array}$ & $\begin{array}{c}9 \% \\
{[65 \%-130 \%]}\end{array}$ & - & no \\
\hline & b. $30 \mathrm{mg} / \mathrm{d}$ po & - & - & - & $\begin{array}{c}32 \% \\
{[70 \%-130 \%]}\end{array}$ & $\begin{array}{c}43 \% \\
{[65 \%-140 \%]}\end{array}$ & $\begin{array}{c}58 \% \\
{[65 \%-140 \%]}\end{array}$ & $\begin{array}{c}25 \% \\
{[60 \%-130 \%]}\end{array}$ & - & - & - & no \\
\hline \multirow[t]{4}{*}{21} & before treatment & - & - & - & $35 \% *$ & $37 \% *$ & $54 \% *$ & $13 \% *$ & $56 \%$ & $37 \%$ & $\begin{array}{c}\text { ratio ucOC/cOC: } \\
30.3[1.2]\end{array}$ & \\
\hline & a. $70 \mathrm{mg}(38 \mathrm{y})$ & - & - & - & $71 \%$ & $69 \%$ & $90 \%$ & $28 \%$ & $63 \%$ & $48 \%$ & $\begin{array}{c}\text { ratio ucOC/cOC: } \\
11.9[1.2]\end{array}$ & ? \\
\hline & b. $70 \mu \mathrm{g}(47 \mathrm{y})$ & - & - & - & $77 \%$ & $79 \%$ & $84 \%$ & $30 \%$ & $81 \%$ & - & - & $?$ \\
\hline & c. $105 \mu \mathrm{g}(47 \mathrm{y})$ & - & - & - & $94 \%$ & $76 \%$ & $100 \%$ & $37 \%$ & - & - & - & $?$ \\
\hline \multirow[t]{4}{*}{22} & before treatment & - & - & - & $30 \% *$ & $37 \% *$ & $53 \% *$ & $29 \% *$ & - & - & - & $\begin{array}{c}\text { incidental } \\
\text { finding }\end{array}$ \\
\hline & a. $6 \mathrm{mg}(14 \mathrm{y})$ & - & - & - & $34 \%$ & $53 \%$ & $63 \%$ & $39 \%$ & - & - & - & no \\
\hline & b. $14 \mathrm{mg}(20 \mathrm{y})$ & - & - & - & $41 \%$ & $51 \%$ & $59 \%$ & $26 \%$ & $30 \%$ & $17 \%$ & - & no \\
\hline & c. $70 \mathrm{mg}(20 \mathrm{y})$ & - & - & - & $53 \%$ & $59 \%$ & $91 \%$ & $39 \%$ & - & - & - & no \\
\hline \multirow[t]{6}{*}{23} & before treatment & - & - & - & - & $15 \%(V K R /) *$ & $n d$ & $6 \% *$ & - & - & - & \\
\hline & a. $1 \times 1 \mathrm{mg}(10$ days $)$ & - & - & - & - & - & - & $30 \%$ & - & - & - & $?$ \\
\hline & b. $1 \times 1 \mathrm{mg}$ (17 days) & - & - & - & - & - & - & $22 \%$ & - & - & - & ? \\
\hline & c. $30 \mathrm{mg}$ (7 y) & - & - & - & - & $80 \%$ & - & $42 \%$ & - & - & - & $?$ \\
\hline & d. $50 \mathrm{mg}(11 \mathrm{y})$ & - & - & - & $34 \%$ & $47 \%$ & $40 \%$ & $33 \%$ & $55 \%$ & $27 \%$ & - & $?$ \\
\hline & e. $90 \mathrm{mg}(11 \mathrm{y})$ & - & - & - & $51 \%$ & $68 \%$ & $54 \%$ & $51 \%$ & $69 \%$ & $35 \%$ & - & $?$ \\
\hline
\end{tabular}


Table 9. Cont

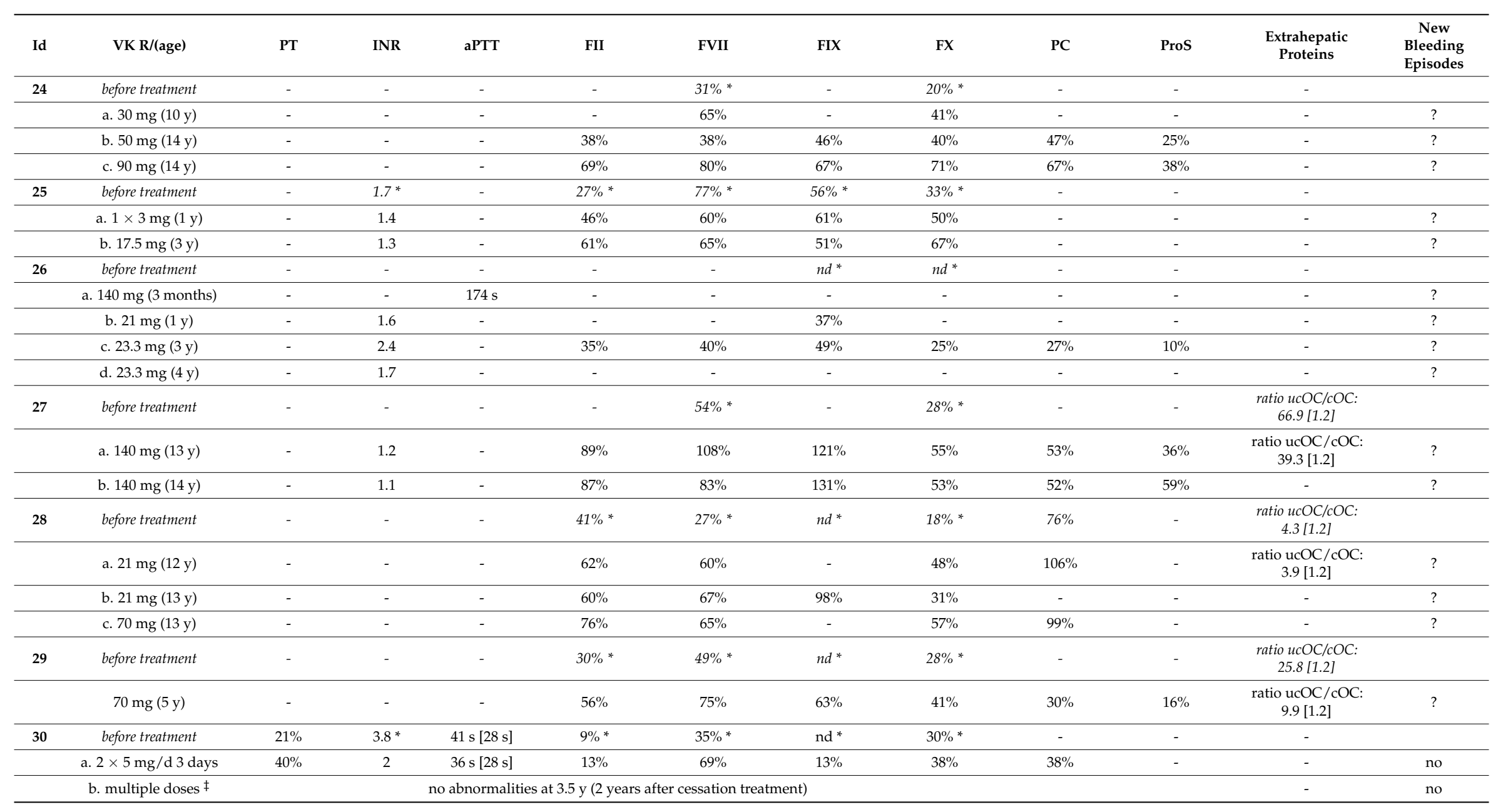


Table 9. Cont.

\begin{tabular}{|c|c|c|c|c|c|c|c|c|c|c|c|c|}
\hline Id & VK R/(age) & PT & INR & aPTT & FII & FVII & FIX & FX & PC & ProS & $\begin{array}{l}\text { Extrahepatic } \\
\text { Proteins }\end{array}$ & $\begin{array}{c}\text { New } \\
\text { Bleeding } \\
\text { Episodes }\end{array}$ \\
\hline \multirow[t]{2}{*}{44} & before treatment & $>100 \mathrm{~s}$ & - & $>150 \mathrm{~s}$ & $0.11 \mathrm{U} / m L^{\S}$ & $0.12 \mathrm{U} / \mathrm{m} \S$ & $0.30 \mathrm{U} / \mathrm{mL}^{\S}$ & $0.09 \mathrm{U} / \mathrm{mL}^{\S}$ & - & - & - & \\
\hline & $2 \mathrm{mg}$ po & - & - & - & good response & $\begin{array}{l}\text { modest } \\
\text { response }\end{array}$ & good response & good response & - & - & - & ? \\
\hline \multirow[t]{2}{*}{45} & before treatment & $30 s$ & - & $38 \mathrm{~s}$ & $0.09 \mathrm{U} / \mathrm{mL}$ * & $0.21 \mathrm{U} / \mathrm{mL}^{*}$ & $0.59 \mathrm{U} / \mathrm{mL}$ & $0.17 \mathrm{U} / \mathrm{mL}$ * & - & - & - & $\begin{array}{l}\text { incidental } \\
\text { finding }\end{array}$ \\
\hline & $1 \mathrm{mg}$ iv & - & - & - & good response & good response & no response & no response & - & - & - & $?$ \\
\hline \multirow[t]{2}{*}{46} & before treatment & $>100$ s [12.8] & - & - & $3 \% *$ & $2 \% *$ & - & $3 \% *$ & - & - & - & \\
\hline & infusion & $14.8 \mathrm{~s}[12.8 \mathrm{~s}]$ & - & - & $72 \%$ & $62 \%$ & & $62 \%$ & - & - & - & no \\
\hline \multirow[t]{2}{*}{47} & before treatment & $98.9 \mathrm{~s}$ & 9* & $53.1 \mathrm{~s}$ & $2 \% *$ & $1.7 \%$ * & $4.7 \% *$ & $2 \% *$ & - & - & $\begin{array}{l}\text { ratio ucOC/cOC: } \\
84.5^{*}\end{array}$ & \\
\hline & $\begin{array}{l}\text { VK1: 5-10 mg/d po or } \\
\text { iv (VK1) }\end{array}$ & $95.4 \mathrm{~s} \pm 11.9 \mathrm{~s}$ & $8.9 \pm 0.8$ & $40.0 \mathrm{~s} \pm 7.3 \mathrm{~s}$ & $3.7 \% \pm 0.9 \%$ & $3.2 \% \pm 1.7 \%$ & $9.1 \% \pm 2.8 \%$ & $4.7 \% \pm 2.1 \%$ & $4.1 \% \pm 2.1 \%$ & $5.6 \% \pm 0.8 \%$ & $\begin{array}{c}\text { ratio ucOC/cOC: } \\
9.5 *\end{array}$ & yes \\
\hline
\end{tabular}

?: not mentioned (in column "new bleeding episodes"); 14 bp del I1: 14 base pair deletion intron 1; (a) PTT: (activated) partial thromboplastin time; d: day (only in column "VK R/"), cOC: gamma-carboxylated osteocalcin; dp-ucMGP: desphospho-uncarboxylated matrix gla protein; FII: coagulation factor II; FVII: coagulation factor VII; FIX: coagulation factor IX; FX: coagulation factor X; Id: identification number; IM: intramuscular; INR: international normalized ratio; nd: not described; VK R/: vitamin K therapy; PC: protein C; po: per os (oral); ProS: protein S; PT: prothrombin time; s: seconds (only in columns "PT and aPTT"); sc: subcutaneous; TMD: transmembrane domain; VK: vitamin K; ucOC: uncarboxylated osteocalcin; y: year (only in column "VK R/"); ${ }^{+}$therapy also included: $+41 \mathrm{mg}$ MK-4/day and $2 \mathrm{mg}$ MK-7/day for 6 months; MK-4 and MK-7 are homologue of vitamin K2; * no reference values in original article or no values, but clearly stated in full-text as deficient; $¥ 2 \times 5 \mathrm{mg}$ VK IM/week ( 2 weeks), then $5 \mathrm{mg} \mathrm{VK} \mathrm{IM/week} \mathrm{(4} \mathrm{weeks),} \mathrm{then} 5 \mathrm{mg}$ VK IM/month (16 months), then cessation therapy with continued normal coagulation parameters; ${ }^{\S}$ deficient factor IX confirmed at 9 years of age. 


\section{Discussion}

For this systematic review, we assessed all patients described in literature with cardiac, dermatological, ophthalmological, osseous and/or coagulation abnormalities, caused by GGCX mutations, and explored possible genotype-phenotype correlations. As the number of patients suffering from these orphan diseases is too small to allow valid statistical interpretation of the data, we did not perform a meta-analysis. However, based on the data, we identified a trend that the presence of at least one GGCX mutations in the HTTM domain may predispose for the occurrence of a cardiac and/or osseous phenotype. Further, there seems to be an association between aging and the occurrence of a skin and, less clearly, an ocular phenotype rather than a link with a specific genotype. However, most of the patients with an ophthalmological phenotype also had at least one HTTM domain mutation. Regarding the bleeding phenotype, severely affected patients seem to have homozygous mutations or compound heterozygous mutations affecting the same protein domain.

\subsection{Cardiac Phenotype}

To date, no direct pathophysiological link has been established between GGCX mutations and cardiac abnormalities. However, Gas6-a VKDP gamma-carboxylated by GGCX-activates AXL (AXL receptor tyrosine kinase; OMIM*109135), a receptor tyrosine kinase (RTK) that interacts with non-muscle myosin IIB, an essential protein for normal development of the murine heart [51,52]. As all patients with cardiac involvement had at least one mutation located in the HTTM domain, possibly this domain plays a role in Gas6 carboxylation, which could explain the cardiac problems in patients. Cardiac anomalies were found in 8/47 patients (17\%) with GGCX mutations, in contrast to 4/63 patients $(6 \%)$ with fetal warfarin syndrome, caused by inhibition of gamma-carboxylation by warfarin administration during pregnancy [53]. A possible explanation for this discrepancy is that warfarin is a dose-dependent inhibitor of the VK cycle and GGCX mutations lead to a permanent and persistent defect in gamma-carboxylation [54]. Deficiency of another VKDP, MGP, has also been associated with cardiac involvement, including pulmonary artery stenosis and ventricular septal defects $[55,56]$.

As in the study cohort all patients with cardiac problems have at least one mutation in the HTTM domain, patients with a GGCX mutation in this domain might benefit from an echocardiography to rule out possible anomalies or to enable early initiation of treatment if a heart defect is identified. This is for example the case in patients with a small to moderate patent ductus arteriosus Botalli, who may remain asymptomatic during childhood, leaving the defect thus undetected. Some of these patients develop congestive heart failure in early adulthood due to a chronic, left heart overload [57]. Early diagnosis can enable early surgical closure of the patent ductus arteriosus Botalli, hereby preventing the development of heart failure.

\subsection{Dermatological Phenotype}

The patients diagnosed with skin symptoms were often described with a less severe bleeding phenotype, suggesting the presence of a residual carboxylation capacity. Recently, an exon 3 deletion, present in P13 and P31-P43 was proven to completely inactivate the GGCX enzyme. In P31-P43, this mutation (c.373+3G $>$ T), which is localized in TMD1 and -2, was present homozygously and led to cutis laxa, a pigmentary retinopathy but no VKCFD1. Interestingly, P13 harbored a heterozygous exon 3 deletion, caused by another splice site mutation c.215-1G>T, with the p.(R485P) mutation on the other allele and had VKCFD1 but no dermatological phenotype. Jin et al. showed that p.(R485P) led to a GGCX enzyme with some residual function, which according to the authors played an important role in the development of a bleeding phenotype, as a high dose of VK was necessary to ameliorate the phenotype [58]. These data could indicate that TMD1 and -2 have no significant role in the carboxylation of VK-dependent coagulation factors. Indeed, only four patients with VKCFD1 (P13, P15, and P29) have a heterozygous mutation in TMD1 and/or TMD2, and all but one had a second mutation in another GGCX domain. P47 had a homozygous GGCX mutation affecting the HTTM 
(TMD1) and only had VKCFD1 and no skin phenotype. However, the mutation also affected the $\mathrm{N}$-terminal region of the protein, which may be an explanation for the VKCFD1 phenotype in this patient. Further, the absence of a skin phenotype could be due to the young age of the patient when it was described in literature (four years of age at last described follow-up).

Regarding the severity of the skin manifestations, PXE-like dermatological symptoms-mainly cutis laxa-are typically more severe compared to classic PXE patients with regard to their location (beyond flexural areas), number of additional skin folds and the time span during which they develop and aggravate [36]. Interestingly, 21/24 patients discussed in this paper who are older than 18 years, have typical PXE-like skin manifestations (Tables 2 and 5). This could indicate that skin symptoms may be due to an accumulation of certain substances which only leads to symptoms when a critical threshold is reached, irrespective of the patients' genotypes. In this respect, Vanakker et al. showed an accumulation of uncarboxylated MGP and OC, two potent mineralization inhibitors, in patients with PXE-like disorder with multiple combined coagulation factor deficiency [36]. Although the age of onset of skin problems is variable between the described patients (P3-P40), this would indicate that most, if not all, patients with biallelic GGCX mutations develop skin lesions in the course of their disease.

For P13, at birth the putative diagnosis of Williams-Beuren syndrome was made based on his facial gestalt. Even though there is no direct link with VKDP and VKCFD1, this disease is caused by a deletion of the WBSCR (Williams-Beuren syndrome critical region), including the ELN gene (elastin; OMIM*130160), responsible for the arteriopathy in Williams-Beuren syndrome. Further, cardiac involvement (most commonly supravalvular aortic stenosis) and a skin phenotype (soft loose skin) are features of this disease [59]. Moreover, heterozygous ELN mutations are associated with an autosomal dominant type of cutis laxa (ADCL1; OMIM\#123700) [60]. These clinical findings might indicate a possible link between these disease entities, although only one patient in the whole cohort was described with a facies resembling the Williams-Beuren syndrome, rendering the assumption less likely.

Of the remaining 24 patients without skin manifestations, 20 were 18 years old or younger and 21/24 had VKFCD1 (deficiency of the VK-dependent coagulation factors (Tables 2 and 8). Hence, VKFCD1 and the PXE-like disorder with multiple coagulation factor deficiency could belong to a disease spectrum with partly overlapping etiopathogenetic mechanisms, but in whom different GGCX domains are important for the activation of the involved VKDP. However, the young age of these patients could also be an explanation for the absence of a skin phenotype. In severe cases, the additional skin folds may lead to restriction of normal physical activities and may be predilection sites for (severe) skin infections, which is important in patient counseling and follow-up.

Finally, in the analyzed literature, three patients are described with skin symptoms and a digenic inheritance of $A B C C 6$ and GGCX mutations [37,46]. These patients were not included in this analysis because an unambiguous interpretation of the skin features is not possible, as both GGCX and ABCC6 mutation may lead to related skin phenotypes. Typically, the skin phenotype in these patients is less severe than in patients with biallelic GGCX mutations, so it may be worthwhile to perform additional sequencing of the $A B C C 6$ gene in those patients in whom only one GGCX mutation is withheld as it will influence genetic counseling and management.

\subsection{Ophthalmological Phenotype}

Regarding the eye symptoms, all patients with a homozygous skip of exon 3 were diagnosed with a pigmentary retinopathy, a disease mimicking retinitis pigmentosa. In mice, it has already been shown that absence of both ligands of the RTK MerTK (Mer tyrosine kinase proto-oncogene; OMIM*604705), Gas6 and ProS, leads to retinitis pigmentosa [61]. In analogy, such a mechanism could play a role in the development of a pigmentary retinopathy in the two families with a homozygous skip of exon 3 in the GGCX gene. As this mutation is located in the HTTM domain, this could again point to its 
putative roles in the carboxylation of both Gas6 and ProS, similar to what is observed in patients with a cardiac phenotype.

Furthermore, as in 17 of the 24 patients over 18 years of age an ophthalmological phenotype was identified and in only four out of 23 patients with cutis laxa no accompanying eye disease was reported, possibly, the major determinant of developing a GGCX-related retinopathy is also increasing age. Although this link seems less convincing compared to skin manifestations, it should be noted that (mild) angioid streaks are asymptomatic and can easily be overlooked during a routine ophthalmological checkup. In the spectrum, PXE-like skin and eye symptoms may be phenotypes that occur in most patients with increasing age, whereas VKCFD1 may be more variable, with neonatal complications in severe forms to apparent normal coagulation in very mildly affected patients, such as those patients described by Kariminejad et al. [40] with PXE-like skin symptoms, an eye phenotype but no apparent VKCFD1. As mentioned above, possibly distinct GGCX domains play an important part role in the gamma-carboxylation of involved VKDP.

Overall, the PXE-like ophthalmological symptoms (P8, P10, P11, P16, P17, and P18) seem less severe compared to the dermatological features with no functional complications in the described patient cohort. However, as this cohort is small, we cannot exclude the possibility that in some patients with biallelic GGCX mutations more severe PXE eye symptoms may occur with subretinal neovascularization and hence loss of vision if not treated immediately. Further, a pigmentary retinopathy with severe visual dysfunction may occur in some patients. It therefore seems appropriate to follow patients ophthalmologically, certainly from the time they start to develop skin symptoms. In mildly affected patients the typical PXE-like angioid streaks may be very small and thus only be picked up by very sensitive funduscopic imaging, for which confocal near-infrared reflectance imaging is superior compared to other techniques [62,63]. If symptoms are stable for a long time, follow-up may become less stringent; however, to our knowledge, there has thus far not been a comprehensive long-term follow-up study of eye symptoms in patients with biallelic GGCX mutations.

\subsection{Osseous Phenotype}

Bone symptoms in patients with GGCX mutations show an important clinical overlap with other genetic syndromes, such as X-linked chondrodysplasia punctata (an autosomal recessive disorder caused by mutations in the ARSE gene (arylsulphatase E; OMIM*123700), encoding ARSE), Keutel syndrome, due to MGP gene mutations; and the fetal warfarin syndrome [64]. Interestingly, Vanakker et al. confirmed an accumulation of uncarboxylated MGP and OC in patients with the PXE-like syndrome; similarly, an in vitro model for the mutation leading to the Keutel syndrome-like phenotype in P7 showed an abolishment of MGP carboxylation [28,36]. For ARSE, no data are available of a direct association with GGCX. However, it was shown that ARSE is specifically inhibited by warfarin, therefore having a possible role in warfarin embryopathy, thus ARSE could have a role in the VK cycle, which would explain the phenotypic overlap with patients with biallelic GGCX mutations [65]. Further investigation of this interaction proves a valid way to further unravel the association between the VK-dependent pathway and skeletal development.

Finally, all patients with skeletal and/or facial symptoms had at least one GGCX mutation in the HTTM-domain, so putatively this domain not only plays a role in Gas6 and ProS carboxylation but also in MGP (and OC) carboxylation. Because of the association with osteopenia and osteoporosis, patients with a mutation in the HTTM domain may benefit from an early densitometry (as P23 had already developed osteoporosis at 12 years old, first densitometry may be most valuable at a younger age) to facilitate early treatment when a decreased bone density is present. There is no genotypic difference between patients with a complete bone phenotype (chondrodysplasia punctata, reduced bone mass, facial dysmorphisms) or with only some of the osseous features. Therefore, early bone densitometry may better be advised to all patients with at least one mutation in the HTTM domain. 


\subsection{VKCFD1}

Overall, VKCFD1 seems to be variable in severity, clinical presentation and response to VK supplementation in the analyzed patient cohort. However, there seems to be a trend that the genotypes of patients with very early onset of bleeding symptoms ( $<1$ year of age) mainly comprise homozygous mutations or compound heterozygous mutations in or near the same protein domain. Possibly, biallelic hits in the same protein domain lead to a more severe malfunctioning of the carboxylase and thus more severe VKCFD1 symptoms occur in these patients at a younger age. However, this could not be confirmed by the activity of the coagulation factors in these patients, even though it is difficult to compare such values between patients whose coagulation factor function is measured in different labs, as different units and reference values are used, which cannot easily be compared to each other.

None of the patients with severe bleeding symptoms had a skin or eye phenotype. However, this could be a bias, as these severely affected patients are often described at a very young age and no follow-up studies are available, so putative development of cutis laxa or other PXE-like skin and/or eye manifestations at a later age remains a possibility, which is exemplified by the presence of skin symptoms in some of the patients who have a rather mild bleeding phenotype.

In a small subset of the patient cohort carboxylation status of extrahepatic VKDP were measured, and OC carboxylation seemed to respond (to a variable extent) to VK supplementation. Interestingly, in one of these patients, VK treatment did not influence the bleeding phenotype with no significant change in hemostatic parameters and recurrent bleeding episodes after initiation of the treatment. In contrast, another patient showed a distinct amelioration of the coagulation factor function on VK treatment, whereas MGP carboxylation did not increase. This variability in response to VK supplementation may result from different mechanisms in gamma-carboxylation of hemostatic and extrahepatic VKDP [28]. Moreover, different GGCX mutations affect different regions of the GGCX protein, which could interfere with propeptide binding of different VKDP [21]. The cohort is however too small to make definite conclusions.

\section{Materials and Methods}

\subsection{Article Selection and Patient Data Extraction}

For this review, Pubmed was systematically searched for all papers about GGCX-related phenotypes on 14 December 2016, using the following key words: "GGCX OR gamma-glutamyl carboxylase OR Vitamin K-dependent carboxylase OR $\gamma$-carboxylase AND mutation". The inclusion criteria were as follows: all article types were included (case reports and series, systematic reviews, original articles), as the data about the subject is limited; neither the date of publication nor the journal played a role in the selection; only articles in English, French or Dutch were considered; only articles of which the full text was available were included in the analysis; patients should have at least 1 relevant GGCX-related symptom (cardiac, dermatological, ophthalmological, osseous or coagulation feature) with no limitations regarding age, ethnicity or symptoms.

Only articles meeting the inclusion criteria were included in this systematic review. For each patient, patient characteristics (age, sex, nationality or ethnicity, age of first skin symptoms), genotype and the GGCX-related phenotypes (cardiac, dermatological, ophthalmological, osseous and coagulation dysfunction) were extracted from the original article. For the bleeding phenotype, biochemical values of the VK-dependent coagulation factors (FII, FVII, FIX and FX), PT, INR, aPTT an extrahepatic VKDP (if mentioned) were collected. Coagulation factor function was abnormal when they were not within the normal range of the reference value given in the original paper or, if no reference values were mentioned in the article, when it was clearly stated in the report that the coagulation factor function was deficient. Patients with bleeding symptoms under the age of 1 year were defined as severely affected VKCFD1 patients. Patients were only classified in the severe group when the exact age was clearly mentioned in the original article. 


\subsection{Genotype Analysis}

Mutations were annotated according to the Human Genome Variation Society (HGVS) recommendations at the cDNA and protein level. Further, for each mutation the corresponding protein domain was mentioned if possible (Table 2). Reference sequence NM000821.6 (ENST00000233838.8) of the GGCX gene was used to verify the annotation of all mutations at the cDNA and protein level, as this represents the longest transcript and encodes the longest GGCX isoform. If mutations were annotated incorrectly by using a different reference sequence or another unspecified sequence, the annotation was updated using reference sequence NM000821.6, in order to enable comparison of all genotypes and to establish genotype-phenotype correlations in the complete patient cohort.

\section{Conclusions}

Gamma-carboxylation is an essential process in the activation of VKDP, which are important in numerous biological processes, such as blood clotting, inflammation, bone formation and cell proliferation. This posttranslational modification process is executed by the GGCX enzyme. Mutations in the gene encoding GGCX have been linked to multiple distinct phenotypes, affecting the heart, skin, eyes, blood clotting and bone metabolism. This review highlights the importance of mutations in the HTTM domain for at least the cardiac and bone phenotype, as all of the patients had at least one mutation in this domain, whereas multiple patients without cardiac or osseous manifestations had no mutations in the HTTM domain. Further, age was identified as the most important determinant of the development of PXE-like skin symptoms and to a lesser extent ophthalmological manifestations. Finally, distinct parts of the HTTM domain seem to have a specific role in the development of skin symptoms and not of VKCFD1. Based on our results, patients should be informed during genetic counseling about the possibility of skin lesions appearing in the course of their disease, taking into account that these lesions may be subtle at onset. In all, a detailed ophthalmological evaluation should be performed and adequate follow-up should be organized, as apart from a (mild) typical PXE-like retinopathy a pigmentary retinopathy with significant functional implications may also occur. Because of its association with reduced bone mass, a bone densitometry should be offered to all patients harboring at least one mutation in the HTTM domain of GGCX.

The main limitations of this systematic review are the low number of patients with GGCX-related phenotypes and the presence of consanguinity in some of the assessed families. There is a possibility that homozygosity at other loci could play a role in the occurrence of the other GGCX-related phenotypes in these patients. However, for most of these phenotypes, there are clinical discrepancies between siblings, which makes this less suggestive, even though the possibility of variable penetrance cannot be ruled out. These limitations are inherent to this type of autosomal recessive disorders, because most of them are rare hence making it impossible to have large cohorts with only individual probands. Another limitation is the incomplete information regarding the (non-)hemostatic parameters in some of the original papers, which do not mention reference values, making it impossible to correctly interpret the values in comparison to other patients, as the reference values tend to be highly laboratory-dependent. Further, the details of the VK treatment, with regards to mode of administration, VK dose, specific subtype of VK, and duration of the therapy, are often not or incompletely mentioned. These details could possibly influence the response to treatment in the described patients. However, the main purpose of this systematic review was to combine all known and described patients with GGCX-related phenotypes and to explore the possibility of genotype-phenotype correlations for the different phenotypes. This manuscript can be used as a guideline for future research on the GGCX protein structure and function, which then can lead to new insights in the VK cycle.

Supplementary Materials: Supplementary materials can be found at www.mdpi.com/1422-0067/18/2/240/s1.

Acknowledgments: We would like to acknowledge Ariana Kariminejad for providing us with clinical pictures of the PXE-like phenotype with a pigmentary retinopathy; Eva Y. G. De Vilder is a PhD fellow of the Research Foundation-Flanders (Belgium) (FWO14/ASP/084); Olivier M. Vanakker is supported by a BOF research fellowship from the Ghent University; Olivier M. Vanakker is a Senior Clinical Investigator of the research 
Foundation-Flanders (Belgium); This research was also supported by a Methusalem grant of the Special Research Fund (Bijzonder Onderzoeksfonds-BOF) from Ghent University (BOF08/01M01108).

Author Contributions: Eva Y. G. De Vilder and Jens Debacker collected the data; Eva Y. G. De Vilder reviewed and corrected the data; Eva Y. G. De Vilder wrote the manuscript; Olivier M. Vanakker reviewed the manuscript; and Jens Debacker designed Figure 2.

Conflicts of Interest: The authors declare no conflict of interest.

\section{Abbreviations}

AA

ABCC6

ADCL1

aPTT

ARSE

ATP

AXL

cOC

EC

EF

ER

FII

FIX

FVII

FX

Gas6

GGCX

Gla

Glu

GRP

HGVS

HTTM

INR

$\mathrm{kDa}$

MerTK

MGP

OC

OMIM

$\mathrm{P}$ [1-45]

PRGP

PRISMA-P

ProS

PT

PXE

RmlC

RmlC-like

RTK

SNP

TMD

TMG

ucOC

VK

VKDP

VKORC1

WBSCR amino acid

ATP-binding cassette, subfamily $C$, member 6 autosomal dominant cutis laxa, type 1 activated partial thromboplastin time arylsulphatase E

adenosine triphosphate

AXL receptor tyrosine kinase

gamma-carboxylated osteocalcin

Escherichia coli

elastic fiber

endoplasmic reticulum

coagulation factor II

coagulation factor IX

coagulation factor VII

coagulation factor $X$

growth arrest-specific 6

gamma-glutamyl carboxylase

gamma-carboxyglutamate

glutamate

gla-rich protein

Human Genome Variation Society

horizontally transferred transmembrane domain

international normalized ratio

kiloDalton

Mer tyrosine kinase proto-oncogene

matrix gla protein

osteocalcin

online mendelian inheritance in man

patient identification

proline-rich gla protein

preferred reporting items for systematic reviews and meta-analysis protocols

protein $S$

prothrombin time

pseudoxanthoma elasticum

deoxythymidine-6-deoxy-D-xylo-4-hexulose 3,5 epimerase; EC5.1.3.13

RmlC-like jelly roll fold

receptor tyrosine kinase

single nucleotide polymorphism

transmembrane domain

transmembrane gla protein

uncarboxylated osteocalcin

vitamin $\mathrm{K}$

vitamin $\mathrm{K}$-dependent protein

vitamin K epoxide epoxide reductase complex, subunit 1

Williams-Beuren syndrome critical region 


\section{References}

1. Tie, J.-K.; Stafford, D.W. Structural and functional insights into enzymes of the vitamin K cycle. J. Thromb. Haemost. 2016, 14, 236-247. [CrossRef] [PubMed]

2. Stafford, D.W. The vitamin K cycle. J. Thromb. Haemost. 2005, 3, 1873-1878. [CrossRef] [PubMed]

3. Suleiman, L.; Négrier, C.; Boukerche, H. Protein S: A multifunctional anticoagulant vitamin K-dependent protein at the crossroads of coagulation, inflammation, angiogenesis, and cancer. Crit. Rev. Oncol. Hematol. 2013, 88, 637-654. [CrossRef] [PubMed]

4. Cavaco, S.; Viegas, C.S.B.; Rafael, M.S.; Ramos, A.; Magalhães, J.; Blanco, F.J.; Vermeer, C.; Simes, D.C. Gla-rich protein is involved in the cross-talk between calcification and inflammation in osteoarthritis. Cell. Mol. Life Sci. 2016, 73, 1051-1065. [CrossRef] [PubMed]

5. Viegas, C.S.B.; Simes, D.C.; Laizé, V.; Williamson, M.K.; Price, P.A.; Cancela, M.L. Gla-rich protein (GRP), a new vitamin $\mathrm{K}$-dependent protein identified from sturgeon cartilage and highly conserved in vertebrates. J. Biol. Chem. 2008, 283, 36655-36664. [CrossRef] [PubMed]

6. Viegas, C.S.B.; Cavaco, S.; Neves, P.L.; Ferreira, A.; João, A.; Williamson, M.K.; Price, P.A.; Cancela, M.L.; Simes, D.C. Gla-rich protein is a novel vitamin K-dependent protein present in serum that accumulates at sites of pathological calcifications. Am. J. Pathol. 2009, 175, 2288-2298. [CrossRef] [PubMed]

7. Ferron, M.; Lacombe, J.; Germain, A.; Oury, F.; Karsenty, G. GGCX and VKORC1 inhibit osteocalcin endocrine functions. J. Cell Biol. 2015, 208, 761-776. [CrossRef] [PubMed]

8. Lek, M.; Karczewski, K.J.; Minikel, E.V.; Samocha, K.E.; Banks, E.; Fennell, T.; O’Donnell-Luria, A.H.; Ware, J.S.; Hill, A.J.; Cummings, B.B.; et al. Exome Aggregation Consortium Analysis of protein-coding genetic variation in 60,706 humans. Nature 2016, 536, 285-291. [CrossRef] [PubMed]

9. Parker, C.H.; Morgan, C.R.; Rand, K.D.; Engen, J.R.; Jorgenson, J.W.; Stafford, D.W. A conformational investigation of propeptide binding to the integral membrane protein $\gamma$-glutamyl carboxylase using nanodisc hydrogen exchange mass spectrometry. Biochemistry 2014, 53, 1511-1520. [CrossRef] [PubMed]

10. Schultz, J. HTTM, a horizontally transferred transmembrane domain. Trends Biochem. Sci. 2004, $29,4-7$. [CrossRef] [PubMed]

11. Giraud, M.F.; Leonard, G.A.; Field, R.A.; Berlind, C.; Naismith, J.H. RmlC, the third enzyme of dTDP-L-rhamnose pathway, is a new class of epimerase. Nat. Struct. Biol. 2000, 7, 398-402. [PubMed]

12. Tie, J.-K.; Zheng, M.-Y.; Hsiao, K.-L.N.; Perera, L.; Stafford, D.W.; Straight, D.L. Transmembrane domain interactions and residue proline 378 are essential for proper structure, especially disulfide bond formation, in the human vitamin K-dependent gamma-glutamyl carboxylase. Biochemistry 2008, 47, 6301-6310. [CrossRef] [PubMed]

13. Brenner, B.; Sánchez-Vega, B.; Wu, S.M.; Lanir, N.; Stafford, D.W.; Solera, J. A missense mutation in gamma-glutamyl carboxylase gene causes combined deficiency of all vitamin K-dependent blood coagulation factors. Blood 1998, 92, 4554-4559. [PubMed]

14. Mutucumarana, V.P.; Stafford, D.W.; Stanley, T.B.; Jin, D.Y.; Solera, J.; Brenner, B.; Azerad, R.; Wu, S.M. Expression and characterization of the naturally occurring mutation L394R in human gamma-glutamyl carboxylase. J. Biol. Chem. 2000, 275, 32572-32577. [CrossRef] [PubMed]

15. Mutucumarana, V.P.; Acher, F.; Straight, D.L.; Jin, D.-Y.; Stafford, D.W. A conserved region of human vitamin K-dependent carboxylase between residues 393 and 404 is important for its interaction with the glutamate substrate. J. Biol. Chem. 2003, 278, 46488-46493. [CrossRef] [PubMed]

16. Tie, J.-K.; Zheng, M.-Y.; Pope, R.M.; Straight, D.L.; Stafford, D.W. Identification of the N-linked glycosylation sites of vitamin K-dependent carboxylase and effect of glycosylation on carboxylase function. Biochemistry 2006, 45, 14755-14763. [CrossRef] [PubMed]

17. Tie, J.-K.; Jin, D.-Y.; Loiselle, D.R.; Pope, R.M.; Straight, D.L.; Stafford, D.W. Chemical modification of cysteine residues is a misleading indicator of their status as active site residues in the vitamin K-dependent gamma-glutamyl carboxylation reaction. J. Biol. Chem. 2004, 279, 54079-54087. [CrossRef] [PubMed]

18. Tie, J.-K.; Mutucumarana, V.P.; Straight, D.L.; Carrick, K.L.; Pope, R.M.; Stafford, D.W. Determination of disulfide bond assignment of human vitamin K-dependent gamma-glutamyl carboxylase by matrix-assisted laser desorption/ionization time-of-flight mass spectrometry. J. Biol. Chem. 2003, 278, 45468-45475. [CrossRef] [PubMed] 
19. Hallgren, K.W.; Zhang, D.; Kinter, M.; Willard, B.; Berkner, K.L. Methylation of $\gamma$-carboxylated Glu (Gla) allows detection by liquid chromatography-mass spectrometry and the identification of Gla residues in the $\gamma$-glutamyl carboxylase. J. Proteome Res. 2013, 12, 2365-2374. [CrossRef] [PubMed]

20. Weston, B.W.; Monahan, P.E. Familial deficiency of vitamin K-dependent clotting factors. Haemophilia 2008, 14, 1209-1213. [CrossRef] [PubMed]

21. Watzka, M.; Geisen, C.; Scheer, M.; Wieland, R.; Wiegering, V.; Dörner, T.; Laws, H.-J.; Gümrük, F.; Hanalioglu, S.; Unal, S.; et al. Bleeding and non-bleeding phenotypes in patients with GGCX gene mutations. Thromb. Res. 2014, 134, 856-865. [CrossRef] [PubMed]

22. Spronk, H.M.; Farah, R.A.; Buchanan, G.R.; Vermeer, C.; Soute, B.A. Novel mutation in the gamma-glutamyl carboxylase gene resulting in congenital combined deficiency of all vitamin K-dependent blood coagulation factors. Blood 2000, 96, 3650-3652. [PubMed]

23. Rost, S.; Fregin, A.; Koch, D.; Compes, M.; Müller, C.R.; Oldenburg, J. Compound heterozygous mutations in the gamma-glutamyl carboxylase gene cause combined deficiency of all vitamin K-dependent blood coagulation factors. Br. J. Haematol. 2004, 126, 546-549. [CrossRef] [PubMed]

24. Darghouth, D.; Hallgren, K.W.; Shtofman, R.L.; Mrad, A.; Gharbi, Y.; Maherzi, A.; Kastally, R.; le Ricousse, S.; Berkner, K.L.; Rosa, J.-P. Compound heterozygosity of novel missense mutations in the $\gamma$-glutamyl-carboxylase gene causes hereditary combined vitamin K-dependent coagulation factor deficiency. Blood 2006, 108, 1925-1931. [CrossRef] [PubMed]

25. Titapiwatanakun, R.; Rodriguez, V.; Middha, S.; Dukek, B.A.; Pruthi, R.K. Novel splice site mutations in the gamma glutamyl carboxylase gene in a child with congenital combined deficiency of the vitamin K-dependent coagulation factors (VKCFD). Pediatr. Blood Cancer 2009, 53, 92-95. [CrossRef] [PubMed]

26. Lunghi, B.; Redaelli, R.; Caimi, T.M.; Corno, A.R.; Bernardi, F.; Marchetti, G. Novel phenotype and $\gamma$-glutamyl carboxylase mutations in combined deficiency of vitamin K-dependent coagulation factors. Haemophilia 2011, 17, 822-824. [CrossRef] [PubMed]

27. Thomas, A.; Stirling, D. Four factor deficiency. Blood Coagul. Fibrinolysis 2003, 14, 55-57. [CrossRef]

28. Tie, J.-K.; Carneiro, J.D.A.; Jin, D.-Y.; Martinhago, C.D.; Vermeer, C.; Stafford, D.W. Characterization of vitamin K-dependent carboxylase mutations that cause bleeding and nonbleeding disorders. Blood 2016, 127, 1847-1855. [CrossRef] [PubMed]

29. Darghouth, D.; Hallgren, K.W.; Odile, I.; Bazaa, A.; Berkner, K.L.; Rosa, J.P. Compound heterozygosity of a W493C substitution and R704/premature stop codon within the $\gamma$-glutamyl carboxylase in combined vitamin K-dependent coagulation factor deficiency in a french family. Blood 2009, 114, 1302.

30. Dasi, M.A.; Gonzalez-Conejero, R.; Izquierdo, S.; Padilla, J.; Garcia, J.L.; Garcia-Barberá, N.; Argilés, B.; la Morena-Barrio, M.E.; Hernández-Sánchez, J.M.; Hernández-Rivas, J.M.; et al. Uniparental disomy causes deficiencies of vitamin K-dependent proteins. J. Thromb. Haemost. 2016, 14, 2410-2418. [CrossRef] [PubMed]

31. Rost, S.; Fregin, A.; Ivaskevicius, V.; Conzelmann, E.; Hörtnagel, K.; Pelz, H.-J.; Lappegard, K.; Seifried, E.; Scharrer, I.; Tuddenham, E.G.D.; et al. Mutations in VKORC1 cause warfarin resistance and multiple coagulation factor deficiency type II. Nature 2004, 427, 537-541. [CrossRef] [PubMed]

32. Oldenburg, J.; Marinova, M.; Müller-Reible, C.; Watzka, M. Physiological role of vitamin K dependent proteins. In Vitamin K, 1st ed.; Litwack, G., Ed.; Academic Press (Elsevier): Amsterdam, The Netherlands, 2008; pp. 51-52.

33. Marchetti, G.; Caruso, P.; Lunghi, B.; Pinotti, M.; Lapecorella, M.; Napolitano, M.; Canella, A.; Mariani, G.; Bernardi, F. Vitamin K-induced modification of coagulation phenotype in VKORC1 homozygous deficiency. J. Thromb. Haemost. 2008, 6, 797-803. [CrossRef] [PubMed]

34. De Vilder, E.Y.G.; Hosen, M.J.; Vanakker, O.M. The ABCC6 Transporter as a paradigm for networking from an orphan disease to complex disorders. Biomed. Res. Int. 2015, 2015, 648569-648618. [CrossRef] [PubMed]

35. Campens, L.; Vanakker, O.M.; Trachet, B.; Segers, P.; Leroy, B.P.; de Zaeytijd, J.; Voet, D.; de Paepe, A.; de Backer, T.; de Backer, J. Characterization of cardiovascular involvement in pseudoxanthoma elasticum families. Arterioscler. Thromb. Vasc. Biol. 2013, 33, 2646-2652. [CrossRef] [PubMed]

36. Vanakker, O.M.; Martin, L.; Gheduzzi, D.; Leroy, B.P.; Loeys, B.L.; Guerci, V.I.; Matthys, D.; Terry, S.F.; Coucke, P.J.; Pasquali-Ronchetti, I.; et al. Pseudoxanthoma elasticum-like phenotype with cutis laxa and multiple coagulation factor deficiency represents a separate genetic entity. J. Investig. Dermatol. 2007, 127, 581-587. [CrossRef] [PubMed] 
37. Li, Q.; Grange, D.K.; Armstrong, N.L.; Whelan, A.J.; Hurley, M.Y.; Rishavy, M.A.; Hallgren, K.W.; Berkner, K.L.; Schurgers, L.J.; Jiang, Q.; et al. Mutations in the GGCX and ABCC6 genes in a family with pseudoxanthoma elasticum-like phenotypes. J. Investig. Dermatol. 2009, 129, 553-563. [CrossRef] [PubMed]

38. Lewis, K.G.; Bercovitch, L.; Dill, S.W.; Robinson-Bostom, L. Acquired disorders of elastic tissue: Part II. Decreased elastic tissue. J. Am. Acad. Dermatol. 2004, 51, 165-185. [CrossRef] [PubMed]

39. Vanakker, O.M.; Leroy, B.P.; Schurgers, L.J.; Vermeer, C.; Coucke, P.J.; de Paepe, A. Atypical presentation of pseudoxanthoma elasticum with abdominal cutis laxa: Evidence for a spectrum of ectopic calcification disorders? Am. J. Med. Genet. A 2011, 155, 2855-2859. [CrossRef] [PubMed]

40. Kariminejad, A.; Bozorgmehr, B.; Najafi, A.; Khoshaeen, A.; Ghalandari, M.; Najmabadi, H.; Kariminejad, M.H.; Vanakker, O.M.; Hosen, M.J.; Malfait, F.; et al. Retinitis pigmentosa, cutis laxa, and pseudoxanthoma elasticum-like skin manifestations associated with GGCX mutations. J. Investig. Dermatol. 2014, 134, 2331-2338. [CrossRef] [PubMed]

41. Tian, L.; Zhang, J.; Xiao, S.; Huang, J.; Zhang, Y.; Shen, J. Impact of polymorphisms of the GGCX gene on maintenance warfarin dose in Chinese populations: Systematic review and meta-analysis. Meta Gene 2015, 5, 43-54. [CrossRef] [PubMed]

42. Iwuchukwu, O.F.; Ramirez, A.H.; Shi, Y.; Bowton, E.A.; Kawai, V.K.; Schildcrout, J.S.; Roden, D.M.; Denny, J.C.; Stein, C.M. Genetic determinants of variability in warfarin response after the dose-titration phase. Pharmacogenet. Genom. 2016, 26, 510-516. [CrossRef] [PubMed]

43. Hamadeh, I.S.; Shahin, M.H.; Lima, S.M.; Oliveira, F.; Wilson, L.; Khalifa, S.I.; Langaee, T.Y.; Cooper-DeHoff, R.M.; Cavallari, L.H.; Johnson, J.A. Impact of GGCX, STX1B and FPGS polymorphisms on warfarin dose requirements in European-Americans and Egyptians. Clin. Transl. Sci. 2016, 9, 36-42. [CrossRef] [PubMed]

44. Wakamiya, T.; Hokosaki, T.; Tsujimoto, S.-I.; Kadota, K.; Nakano, Y.; Watanabe, S.; Iwamoto, M.; Yanagimachi, M.; Ito, S. Effect of VKORC1, CYP2C9, CFP4F2, and GGCX gene polymorphisms on warfarin dose in Japanese pediatric patients. Mol. Diagn. Ther. 2016, 20, 393-400. [CrossRef] [PubMed]

45. Shamseer, L.; Moher, D.; Clarke, M.; Ghersi, D.; Liberati, A.; Petticrew, M.; Shekelle, P.; Stewart, L.A.; PRISMA-P Group. Preferred reporting items for systematic review and meta-analysis protocols (PRISMA-P) 2015: Elaboration and explanation. BMJ 2015, 349, 7647. [CrossRef] [PubMed]

46. Hosen, M.J.; van Nieuwerburgh, F.; Steyaert, W.; Deforce, D.; Martin, L.; Leftheriotis, G.; de Paepe, A.; Coucke, P.J.; Vanakker, O.M. Efficiency of exome sequencing for the molecular diagnosis of pseudoxanthoma elasticum. J. Investig. Dermatol. 2015, 135, 992-998. [CrossRef] [PubMed]

47. Goldsmith, G.H.; Pence, R.E.; Ratnoff, O.D.; Adelstein, D.J.; Furie, B. Studies on a family with combined functional deficiencies of vitamin K-dependent coagulation factors. J. Clin. Investig. 1982, 69, 1253-1260. [CrossRef] [PubMed]

48. Li, Q.; Schurgers, L.J.; Smith, A.C.M.; Tsokos, M.; Uitto, J.; Cowen, E.W. Co-existent pseudoxanthoma elasticum and vitamin K-dependent coagulation factor deficiency: Compound heterozygosity for mutations in the GGCX gene. Am. J. Pathol. 2009, 174, 534-540. [CrossRef] [PubMed]

49. Rost, S.; Geisen, C.; Fregin, A.; Seifried, E.; Müller, C.R.; Oldenburg, J. Founder mutation Arg485Pro led to recurrent compound heterozygous GGCX genotypes in two German patients with VKCFD type 1. Blood Coagul. Fibrinolysis 2006, 17, 503-507. [CrossRef] [PubMed]

50. Mousallem, M.; Spronk, H.M.; Sacy, R.; Hakime, N.; Soute, B.A. Congenital combined deficiencies of all vitamin K-dependent coagulation factors. Thromb. Haemost. 2001, 86, 1334-1336. [PubMed]

51. Tullio, A.N.; Accili, D.; Ferrans, V.J.; Yu, Z.X.; Takeda, K.; Grinberg, A.; Westphal, H.; Preston, Y.A.; Adelstein, R.S. Nonmuscle myosin II-B is required for normal development of the mouse heart. Proc. Natl. Acad. Sci. USA 1997, 94, 12407-12412. [CrossRef] [PubMed]

52. Ma, X.; Adelstein, R.S. In vivo studies on nonmuscle myosin II expression and function in heart development. Front Biosci. 2012, 17, 545-555. [CrossRef]

53. Van Driel, D.; Wesseling, J.; Sauer, P.J.J.; Touwen, B.C.L.; van der Veer, E.; Heymans, H.S.A. Teratogen update: Fetal effects after in utero exposure to coumarins overview of cases, follow-up findings, and pathogenesis. Teratology 2002, 66, 127-140. [CrossRef] [PubMed] 
54. Choonara, I.A.; Malia, R.G.; Haynes, B.P.; Hay, C.R.; Cholerton, S.; Breckenridge, A.M.; Preston, F.E.; Park, B.K. The relationship between inhibition of vitamin K1 2,3-epoxide reductase and reduction of clotting factor activity with warfarin. Br. J. Clin. Pharmacol. 1988, 25, 1-7. [CrossRef] [PubMed]

55. Hur, D.J.; Raymond, G.V.; Kahler, S.G.; Riegert-Johnson, D.L.; Cohen, B.A.; Boyadjiev, S.A. A novel MGP mutation in a consanguineous family: Review of the clinical and molecular characteristics of Keutel syndrome. Am. J. Med. Genet. A 2005, 135, 36-40. [CrossRef] [PubMed]

56. Fryns, J.P.; van Fleteren, A.; Mattelaer, P.; van den Berghe, H. Calcification of cartilages, brachytelephalangy and peripheral pulmonary stenosis: Confirmation of the Keutel syndrome. Eur. J. Pediatr. 1984, 142, 201-203. [CrossRef] [PubMed]

57. Chugh, R.; Salem, M.M. Echocardiography for patent ductus arteriosus including closure in adults. Echocardiography 2015, 32, 125-139. [CrossRef] [PubMed]

58. Jin, D.-Y.; Vermeer, C.; Stafford, D.W.; Tie, J.-K. Splice-site mutation of exon 3 deletion in the $\gamma$-glutamyl carboxylase gene causes inactivation of the enzyme. J. Investig. Dermatol. 2016, 136, 2314-2317. [CrossRef] [PubMed]

59. Pober, B.R. Williams-Beuren syndrome. N. Engl. J. Med. 2010, 362, 239-252. [CrossRef] [PubMed]

60. Callewaert, B.; Renard, M.; Hucthagowder, V.; Albrecht, B.; Hausser, I.; Blair, E.; Dias, C.; Albino, A.; Wachi, H.; Sato, F.; et al. New insights into the pathogenesis of autosomal-dominant cutis laxa with report of five ELN mutations. Hum. Mutat. 2011, 32, 445-455. [CrossRef] [PubMed]

61. Burstyn-Cohen, T.; Lew, E.D.; Través, P.G.; Burrola, P.G.; Hash, J.C.; Lemke, G. Genetic dissection of TAM receptor-ligand interaction in retinal pigment epithelial cell phagocytosis. Neuron 2012, 76, 1123-1132. [CrossRef] [PubMed]

62. Charbel Issa, P.; Finger, R.P.; Holz, F.G.; Scholl, H.P.N. Multimodal imaging including spectral domain OCT and confocal near infrared reflectance for characterization of outer retinal pathology in pseudoxanthoma elasticum. Investig. Ophthalmol. Vis. Sci. 2009, 50, 5913-5918. [CrossRef] [PubMed]

63. Gliem, M.; Zaeytijd, J.D.; Finger, R.P.; Holz, F.G.; Leroy, B.P.; Charbel Issa, P. An update on the ocular phenotype in patients with pseudoxanthoma elasticum. Front. Genet. 2013, 4, 14. [CrossRef] [PubMed]

64. De Vilder, E.Y.; Vanakker, O.M. From variome to phenome: Pathogenesis, diagnosis and management of ectopic mineralization disorders. World J. Clin. Cases 2015, 3, 556-574. [PubMed]

65. Puca, A.A.; Zollo, M.; Repetto, M.; Andolfi, G.; Guffanti, A.; Simon, G.; Ballabio, A.; Franco, B. Identification by shotgun sequencing, genomic organization, and functional analysis of a fourth arylsulfatase gene (ARSF) from the Xp22.3 region. Genomics 1997, 42, 192-199. [CrossRef] [PubMed] 